\title{
Deep-sea ophiuroids (Echinodermata) from reducing and non-reducing environments in the North Atlantic Ocean
}

\author{
Sabine Stöhr* ${ }^{\ddagger}$ and Michel Segonzac ${ }^{\dagger}$ \\ *Swedish Museum of Natural History, Department of Invertebrate Zoology, Box 50007, 10405 Stockholm, Sweden. \\ ${ }^{\dagger}$ IFREMER, Centre de Brest, DRO/Environnement profond-Centob, BP 70, 29280 Plouzané, France. \\ ${ }^{\ddagger}$ Corresponding author, e-mail: sabine.stohr@nrm.se
}

\begin{abstract}
The animal communities associated with the deep-sea reducing environment have been studied for almost 30 years, but until now only a single species of ophiuroid, Ophioctenella acies, has been found at both hydrothermal vents and methane cold seeps. Since the faunal overlap between vent and seep communities is small and many endemic species have been found among other taxa (e.g. Mollusca, Crustacea), additional species of ophiuroids were expected at previously unstudied sites. Chemical compositions at reducing sites differ greatly from the nearby bathyal environment. Generally, species adapted to chemosynthetic environments are not found in non-chemosynthetic habitats, but occasional visitors of other bathyal species to vent and seep sites have been recorded among many taxa except ophiuroids. This paper presents an analysis of the ophiuroid fauna found at hydrothermal vents and non-reducing nearby sites on the Mid-Atlantic Ridge and on methane cold seeps in the Gulf of Mexico, at Blake Ridge off South Carolina and south of Barbados. In addition to O. acies, four species were found at vents, Ophiactis tyleri sp. nov., Ophiocten centobi, Ophiomitra spinea and Ophiotreta valenciennesi rufescens. While Ophioctenella acies appears to be restricted to chemosynthetic areas, the other four species were also found in other bathyal habitats. They also occur in low numbers (mostly single individuals), whereas species adapted to hydrothermal areas typically occur in large numbers. Ophioscolex tripapillatus sp. nov. and Ophiophyllum atlanticum sp. nov. are described from nearby non-chemosynthetic sites. In a cold seep south of Barbados, three species of ophiuroids were found, including Ophioctenella acies, Amphiura sp., Ophiacantha longispina sp. nov. and Ophioplinthaca chelys. From the cold seeps at Blake Ridge and the Gulf of Mexico, Ophienigma spinilimbatum gen. et sp. nov. is described, likely restricted to the reducing environment. Ophiotreta valenciennesi rufescens occurred abundantly among Lophelia corals in the Gulf of Mexico seeps, which is the first record of this species from the West Atlantic. Habitat descriptions complement the taxonomic considerations, and the distribution of the animals in reducing environments is discussed.
\end{abstract}

\section{INTRODUCTION}

Almost 30 years have passed since the discovery of animal communities associated with the deep-sea reducing environment (Tyler et al., 2003) and the number of species known from them has been increasing continually with the exploration of new sites. While the phylum Echinodermata dominates the errant megafauna on the deep-sea floor with regard to numbers of both species and individuals (Gage \& Tyler, 1991), echinoderms were long thought to be underrepresented at hydrothermal vents (Desbruyères \& Segonzac, 1997). Among the echinoderms found at vents and seeps, holothurians of the genus Chiridota Eschscholtz, 1829 are the most abundant and species-rich. They have been reported from Snake Pit on the Mid-Atlantic Ridge (MAR) (Segonzac, 1992) and they are abundant in the cold seeps at Florida Escarpment (Hecker, 1985), Blake Ridge (Van Dover et al., 2003), and in the Pacific (Desbruyères et al., 1994). Few echinoids have been found at vents, but the rare Echinus alexandri Danielssen \& Koren, 1883, known from other bathyal environments (Mortensen, 1927), occurs at the Lucky Strike vent site (Desbruyères \& Segonzac, 1997; Desbruyères et al., 2001), thus representing one of the few species in common between vents and other habitats. Numerous cake urchins Sarsiaster griegii Mortensen, 1950 (associated with chiridotid holothurians) were collected at the cold-seep site Blake Ridge, off South Carolina (Van Dover et al., 2003), but no echinoid endemic to reducing sites is known. Recently, an undescribed asteroid has been observed on active submarine volcanoes off New Zealand (Cosel \& Marshall, 2003), possibly the first representative of this class endemic to a vent site. Ophiuroids, which have the highest abundances of all deep-sea megafauna taxa in non-reducing environments (Gage \& Tyler, 1991), were believed to be absent from the vent habitat, but had been reported from cold seeps (Hecker, 1985). Subsequently, Ophioctenella acies Tyler et al., 1995 was discovered in great densities on the MAR sites TAG (TransAtlantic Geotraverse), Snake Pit and Broken Spur. Recently found also in cold seeps at Blake Ridge and Florida Escarpment (Van Dover et al., 2003), Ophioctenella acies appears to be adapted to these reducing environments and is usually associated with mytilid bivalves Bathymodiolus spp. Kenk \& Wilson, 1985 (Desbruyères \& Segonzac, 1997). In December 1998, unidentified ophiuroids were observed in high density among tubeworms Ternia cf. jerichonana Jones, 1985, on the South-East Pacific Rise (Halanych et al., 


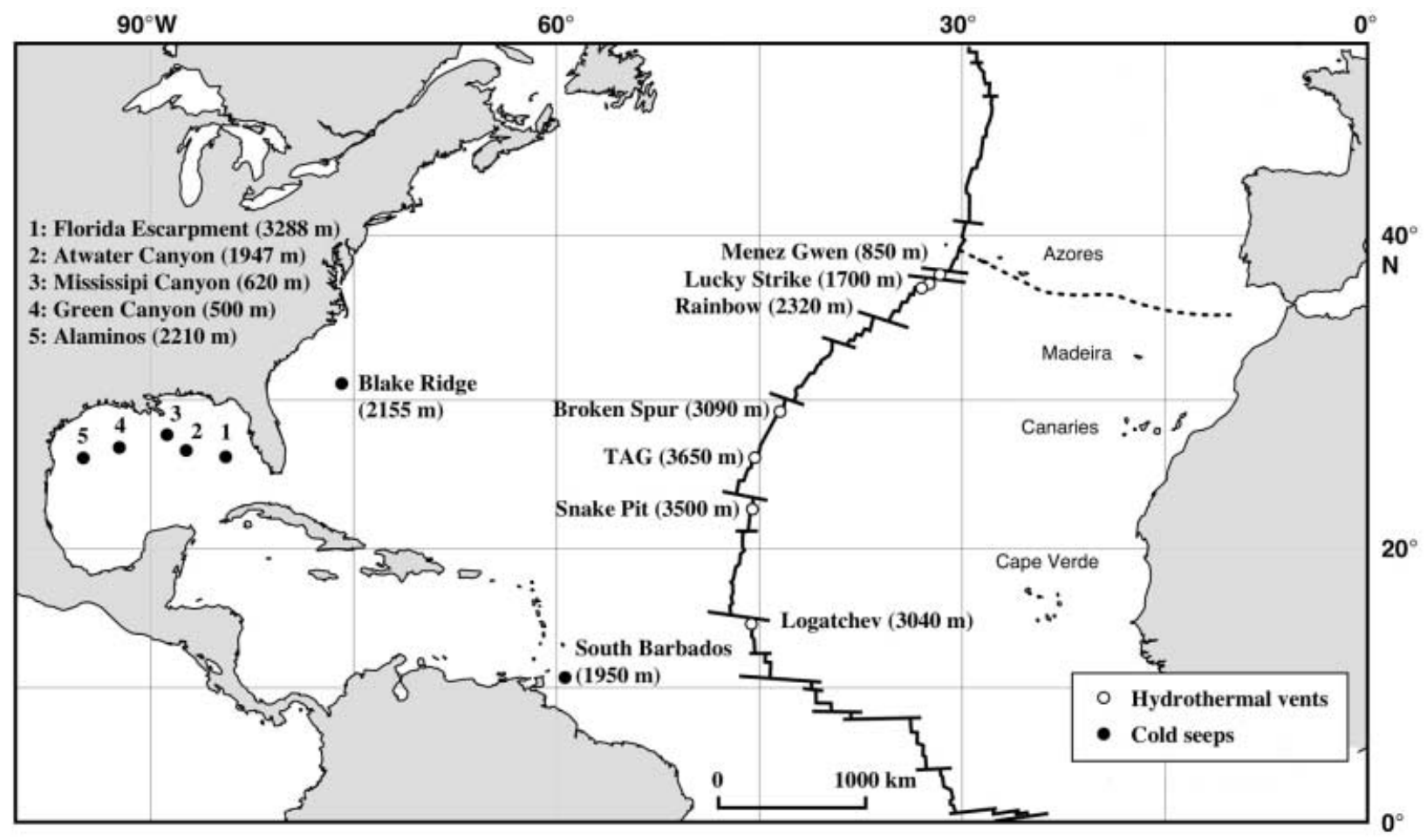

Figure 1. Hydrothermal vent sites on the Mid-Atlantic Ridge, cold seeps at Florida Escarpment, Blake Ridge off South Carolina and south of Barbados, and non-reducing sites in the Bay of Biscay, with depths.

1999, photograph p. 26). Likewise unidentified ophiuroids have been reported from the cold seeps in the Gulf of Mexico and from two more sites in the Pacific Ocean (Sibuet \& Olu, 1998), suggesting that the number of ophiuroid species known as restricted to the reducing environment may increase in the future.

This paper reports ophiuroid species collected recently in the North Atlantic Ocean in several types of environments (Figure 1): hydrothermal vent fields on the MAR (Menez Gwen, 850 m, Lucky Strike, 1700 m, Rainbow, $2300 \mathrm{~m}$, and Logatchev, $3020 \mathrm{~m}$ ), on the MAR segments $38^{\circ} \mathrm{N}$ and $15^{\circ} \mathrm{N}$, and cold seeps (south of Barbados, $1700 \mathrm{~m}$, six sites in the Gulf of Mexico, 500-3300 m and Blake Ridge, off South Carolina, $2155 \mathrm{~m})$. We indicate species that appear to be restricted to the chemosynthetic environment and ones that occur both in this and nonchemosynthetic habitats.

\section{MATERIALS AND METHODS}

The ophiuroids studied here were collected during a large number of cruises between 1992 and 2003 (Table 1). The specimens were collected using a slurp gun and pincers, operated from the submersibles 'Nautile' and 'Alvin' as well as different remotely operated vehicles. They were sorted after sample washing, fixed in formalin and transferred to ethanol.

Selected specimens were air-dried and mounted on aluminium stubs for scanning electron microscopy (SEM). After gold-coating, they were observed and photographed with a Hitachi FE S-4300. Skeletal elements were dissected by dissolving all soft tissue in household bleach (NaOCl), after which the ossicles were air-dried, mounted and observed by SEM. Type specimens have been deposited at the Muséum National d'Histoire Naturelle (MNHN), Paris, the National Museum of Natural History, Smithsonian Institution, Washington DC (USNM), the Museum of Natural History, Los Angeles County (LACM), the Icelandic Institute and Museum of Natural History (NI), Reykjavik, and the Swedish Museum of Natural History (SMNH), Stockholm. Remaining material has been deposited at the MNHN, some of the samples from Blake Ridge, Florida Escarpment and Atwater Canyon are lodged at the SMNH, USNM and LACM. Collection data for three specimens from the BIOice (Benthic Invertebrates Of Iceland) programme and a specimen collected in the Bay of Biscay by the VITAL cruise are included for taxonomic reasons. Specimen ( $\mathrm{spm}$ ) sizes are indicated by disk diameter (dd), measured with an ocular micrometer. The classification follows the scheme suggested by Smith et al. (1995).

\section{RESULTS}

Tables $2 \& 3$ list the occurrence of ophiuroid species and their abundance in vent, cold seep and deep-sea environments. Ophioctenella acies was found on most MAR hydrothermal vent sites (except Menez Gwen) and on the investigated cold seeps (Figure 2A). Four species are recorded from hydrothermal vents for the first time, Ophiocten centobi Paterson, Tyler \& Gage, 1982, Ophiotreta valenciennesi rufescens Koehler, 1896, Ophiactis tyleri sp. nov., and Ophiomitra spinea Verrill, 1885. New records for cold seeps include Ophioplinthaca chelys (Wyville Thomson, 1877), Amphiura sp., Amphioplus sp., Ophienigma spinilimbatum gen. et sp. nov. (Figure 2B), Ophiacantha longispina sp. nov., and 
Table 1. Recent cruises which collected ophiuroids in reducing and non-reducing environments in the North Atlantic.

\begin{tabular}{|c|c|c|c|c|}
\hline Cruise & Chief Scientist & Ships/ROVs & Region & Date \\
\hline FARANAUT & H. Bougault, Ifremer & $\begin{array}{l}\text { DSV 'Nautile'/NO } \\
\text { 'Atalante' }\end{array}$ & MAR, $15^{\circ} \mathrm{N}$ & 15/03-15/04/1992 \\
\hline DIAPISUB & $\begin{array}{l}\text { J.-C. Faugères, } \\
\text { University of Bordeaux }\end{array}$ & $\begin{array}{l}\text { DSV 'Nautile'/NO } \\
x \text { 'Atalante' }\end{array}$ & South Barbados & 21/12/1992-01/01/1993 \\
\hline DIVANAUT 1 & Y. Fouquet, Ifremer & $\begin{array}{l}\text { DSV 'Nautile'/NO } \\
\text { 'Atalante' }\end{array}$ & $\begin{array}{c}\text { MAR, Lucky Strike, Menez } \\
\text { Gwen and segment } 38^{\circ} \mathrm{N}\end{array}$ & $05-29 / 05 / 1994$ \\
\hline DIVANAUT 2 & $\begin{array}{l}\text { D. Desbruyères \& } \\
\text { A.-M. Alayse, Ifremer }\end{array}$ & $\begin{array}{l}\text { DSV 'Nautile'/NO } \\
\text { 'Atalante' }\end{array}$ & $\begin{array}{l}\text { MAR Lucky Strike } \\
\text { and Menez Gwen }\end{array}$ & $31 / 05-04 / 07 / 1994$ \\
\hline MICROSMOKE & D. Prieur, UBO, Brest & $\begin{array}{l}\text { DSV 'Nautile'/NO } \\
\text { 'Nadir' }\end{array}$ & MAR, Snake Pit, Logatchev & $08 / 11-11 / 12 / 1995$ \\
\hline MARVEL & $\begin{array}{l}\text { D. Desbruyères \& } \\
\text { A.-M. Alayse, Ifremer }\end{array}$ & $\begin{array}{l}\text { DSV 'Nautile'/NO } \\
\text { 'Atalante' }\end{array}$ & $\begin{array}{l}\text { MAR, Lucky Strike, Menez } \\
\text { Gwen, Rainbow, Faumous } \\
\text { Segment }\end{array}$ & 13/08-13/09/1997 \\
\hline PICO & D. Desbruyères, Ifremer & $\begin{array}{l}\text { DSV 'Nautile'/NO } \\
\text { 'Nadir' }\end{array}$ & $\begin{array}{l}\text { MAR, Lucky Strike, Menez } \\
\text { Gwen, Rainbow }\end{array}$ & 25/06-11/07/1998 \\
\hline ROV 'Victor' lère & A.-M. Alayse, Ifremer & $\begin{array}{l}\text { ROV 'Victor'/NO } \\
\text { 'Atalante' }\end{array}$ & $\begin{array}{l}\text { MAR, Lucky Strike vent site } \\
\text { and east wall }\end{array}$ & 03/08-03/09/1998 \\
\hline Florida Escarpment & $\begin{array}{l}\text { C. Van Dover, } \\
\text { Williamsburg, USA }\end{array}$ & DSV 'Alvin’ & Gulf of Mexico & $28-09 / 10 / 2000$ \\
\hline Atwater Canyon & $\begin{array}{l}\text { I. Macdonald \& } \\
\text { G. Van Dover }\end{array}$ & $\begin{array}{l}\text { DSV 'Alvin'/RV } \\
\text { 'Atlantis' }\end{array}$ & Gulf of Mexico & $26 / 10 / 2000$ \\
\hline ATOS & P.-M. Sarradin, Ifremer & $\begin{array}{l}\mathrm{ROV} \text { 'Victor'/NO } \\
\text { 'Atalante' }\end{array}$ & MAR, Lucky Strike, Rainbow & $22 / 06-21 / 07 / 2001$ \\
\hline DIVERSExpedition & C. Van Dover & $\begin{array}{l}\text { DSV 'Alvin'/RV } \\
\text { 'Atlantis' }\end{array}$ & $\begin{array}{l}\text { Logatchev, Snake Pit, Broken } \\
\text { Spur, }\end{array}$ & $26 / 06-29 / 07 / 2001$ \\
\hline Blake Ridge & C. Van Dover & $\begin{array}{l}\text { DSV 'Alvin'/RV } \\
\text { 'Atlantis' }\end{array}$ & $\begin{array}{l}\text { Blake Ridge Diapir, off South } \\
\text { Carolina }\end{array}$ & $25-28 / 09 / 2001$ \\
\hline SEAHMA1 & $\begin{array}{l}\text { F. Barriga, University } \\
\text { of Lisbon }\end{array}$ & $\begin{array}{l}\mathrm{ROV} \text { 'Victor'/NO } \\
\text { 'Atalante' }\end{array}$ & $\begin{array}{l}\text { Mount Saldanha, near } \\
\text { Rainbow, Lucky Strike }\end{array}$ & $29 / 07-14 / 08 / 2002$ \\
\hline VITAL & V. Trenkel, Ifremer & $\begin{array}{l}\text { ROV 'Victor'/NO } \\
\text { 'Atalante' }\end{array}$ & Bay of Biscay & $20 / 08-04 / 09 / 2002$ \\
\hline $\begin{array}{l}\text { Upper Louisiana } \\
\text { Slope }\end{array}$ & $\begin{array}{l}\text { C. Fisher, Penn State } \\
\text { University }\end{array}$ & $\begin{array}{l}\text { DSV 'Johnson } \\
\text { Sea-link'/RV } \\
\text { 'Seward Johnson' II }\end{array}$ & Gulf of Mexico & 14/08-08/09/2003 \\
\hline Deep GoM & $\begin{array}{l}\text { R. Carney, Louisiana } \\
\text { State University }\end{array}$ & $\begin{array}{l}\text { DSV 'Alvin'/RV } \\
\text { 'Atlantis' }\end{array}$ & Gulf of Mexico & $06 / 10-19 / 10 / 2003$ \\
\hline
\end{tabular}

ROVs, remotely operated vehicles; MAR, Mid-Atlantic Ridge.

Ophiotreta valenciennesi rufescens. On several sites along the MAR, twelve species were found in non-vent habitats: Asteroschema inornatum Koehler, 1906, Ophioscolex tripapillatus sp. nov., Ophioplinthaca carduus (Lyman, 1878), Ophiacantha enopla veterna (Koehler, 1907), Ophiacantha crassidens Verrill, 1885, Ophiacantha notata Koehler, 1906, Ophiacantha smitti Ljungman, 1872, Ophiactis abyssicola (M. Sars, 1861), Ophiactis tyleri sp. nov., Ophiura ljungmani (Lyman, 1878), Ophiophyllum atlanticum sp. nov. and Ophiocten centobi. Abundances of these ophiuroids were low at all sites except for Ophioctenella acies (at Snake Pit-Elan and mainly at Logatchev) and Ophienigma spinilimbatum (primarily Blake Ridge). The number of species per site was limited to one or two.

A total of 20 species was found, six previously unknown. Ten species belong to the family Ophiacanthidae (genera Ophiacantha, Ophiomitra, Ophioplinthaca, Ophiotreta, Ophienigma gen. nov.). The second most species-rich family was the Ophiuridae with five species (genera Ophiura, Ophioctenella, Ophiocten, Ophiophyllum), while Ophiactidae (Ophiactis) is represented by two species and Amphiuridae (Amphiura), Ophiomyxidae (Ophioscolex) and Asteroschematidae (Asteroschema) by one species each.

\section{SYSTEMATICS}

Order OPHIURIDA Müller \& Troschel, 1840 Suborder OPHIOMYXINA Fell, 1962

Family OPHIOMYXIDAE Ljungman, 1867

Genus Ophioscolex Müller \& Troschel, 1842 Ophioscolex tripapillatus sp. nov.

(Figure 3)

Holotype

10 mm dd, dried, MNHN EcOs 22795.

\section{Type locality}

DIVANAUT 1, PL904-12, box 3, 20 May 1994, MAR, near Menez Gwen (wall west of MAR), $37^{\circ} 50.94^{\prime} \mathrm{N}$ $31^{\circ} 30.67^{\prime} \mathrm{W}, 1015 \mathrm{~m}$, found on oxidized basalt, with sponges, bryozoa, brachiopods, starfish juvenile, tunicate and a single Ophiactis abyssicola.

\section{Paratypes}

One postlarva, $2 \mathrm{~mm}$ dd, mounted on aluminium stub and gold-coated for SEM, VITAL 188, Bay of Biscay, 
Table 2. Collecting sites of ophiuroids on the Mid-Atlantic Ridge, qualitative collections. Dive numbers preceded by cruise name.

\begin{tabular}{|c|c|c|c|c|c|c|c|}
\hline Site & Dive & Latitude $\mathrm{N}$ & Longitude W & Depth $(\mathrm{m}$ & Species & $\mathrm{N}$ & Status \\
\hline 15th Fracture & FR 10 & $15^{\circ} 35.33^{\prime}$ & $46^{\circ} 45.06^{\prime}$ & 3686 & Ophioplinthaca carduus & 1 & NV \\
\hline 15th Fracture & FR14 & $15^{\circ} 28.75^{\prime}$ & $46^{\circ} 33.56^{\prime}$ & 3435 & Ophioplinthaca carduus & 1 & NV \\
\hline 15th Fracture & FR23 & $15^{\circ} 36.54^{\prime}$ & $46^{\circ} 35.29^{\prime}$ & 4078 & Ophiophyllum atlanticum sp. nov. & 1 & NV \\
\hline Lucky Strike & DIV1 PL900-08 & $37^{\circ} 16.76^{\prime}$ & $32^{\circ} 17.23^{\prime}$ & 1680 & Ophiocten centobi & 1 & $\mathrm{~V}$ \\
\hline Segment $38^{\circ} 20$ & DIV1 PL902-10 & $38^{\circ} 19.73^{\prime}$ & $30^{\circ} 40.38^{\prime}$ & 726 & Ophiactis abyssicola & 1 & NV \\
\hline Segment $38^{\circ} 20$ & DIV1 PL903-11 & $38^{\circ} 18.11^{\prime}$ & $30^{\circ} 40.15^{\prime}$ & 789 & Ophiura ljungmani (postlarva) & 1 & NV \\
\hline Segment $38^{\circ} 20$ & DIV1 PL903-11 & $38^{\circ} 18.97^{\prime}$ & $30^{\circ} 40.54^{\prime}$ & 844 & Ophiactis tyleri sp. nov. & 1 & NV \\
\hline \multirow[t]{2}{*}{ Near Menez Gwen } & DIV1 PL904-12 & $37^{\circ} 50.94^{\prime}$ & $31^{\circ} 30.67^{\prime}$ & 1015 & Ophiactis abyssicola & 1 & NV \\
\hline & & & & & Ophioscolex tripapillatus sp. nov. & 1 & \\
\hline Near Menez Gwen & DIV1 PL905-13 & $37^{\circ} 49.09^{\prime}$ & $31^{\circ} 32.54^{\prime}$ & 697 & Ophiura sp. (postlarvae) & 2 & NV \\
\hline Menez Gwen & DIV1 PL906-14 & $37^{\circ} 49.60^{\prime}$ & $31^{\circ} 31.02^{\prime}$ & 848 & Ophiotreta valenciennesi rufescens & 1 & $\mathrm{~V}$ \\
\hline Lucky Strike & DIV1 PL911-19 & $37^{\circ} 17.35^{\prime}$ & $32^{\circ} 16.96^{\prime}$ & 1727 & Ophioctenella acies & 7 & V \\
\hline Menez Gwen & DIV2 PL922-11 & $37^{\circ} 50.56^{\prime}$ & $31^{\circ} 31.27^{\prime}$ & 842 & Ophiactis tyleri sp. nov. & 1 & V \\
\hline Lucky Strike & DIV2 PL933-22 & $37^{\circ} 17.32^{\prime}$ & $32^{\circ} 16.51^{\prime}$ & 1686 & Ophioctenella acies & 2 & V \\
\hline Snake Pit-Elan & MI PL1022-07 & $22^{\circ} 22.20^{\prime}$ & $44^{\circ} 57.08^{\prime}$ & 3500 & Ophioctenella acies & 1 & V \\
\hline Logatchev-Irina 2 & MI PL1035-20 & $14^{\circ} 45,19^{\prime}$ & $44^{\circ} 58.76^{\prime}$ & 3020 & Ophioctenella acies & 500 & V \\
\hline Logatchev-Irina 2 & MI PL1036-21 & & & 3020 & Ophioctenella acies & 53 & V \\
\hline Lucky Strike & MA PL1193-2 & $37^{\circ} 17.37^{\prime}$ & $32^{\circ} 16.50^{\prime}$ & 1700 & Ophioctenella acies & 1 & V \\
\hline Lucky Strike & MA PL1 194/95 & $37^{\circ} 17.37^{\prime}$ & $32^{\circ} 16.48^{\prime}$ & 1700 & Ophioctenella acies & 11 & V \\
\hline \multirow[t]{2}{*}{ Famous } & MA PL1199-10 & $36^{\circ} 32.26^{\prime}$ & $33^{\circ} 27.40^{\prime}$ & 2300 & Ophiacantha enopla veterna & 2 & NV \\
\hline & & & & & Asteroschema inornatum & 3 & \\
\hline Lucky Strike & MA PL1205-1 & $37^{\circ} 17.66^{\prime}$ & $32^{\circ} 16.88^{\prime}$ & 1664 & Ophioctenella acies & 4 & V \\
\hline Rainbow-Iris 7 & AT PL103-01 & $36^{\circ} 13.77^{\prime}$ & $33^{\circ} 54.12^{\prime}$ & 2275 & Ophioctenella acies & 1 & V \\
\hline Lucky Strike & AT PL110-08 & $37^{\circ} 17.00^{\prime}$ & $32^{\circ} 16.00^{\prime}$ & 1688 & Ophioctenella acies & 1 & V \\
\hline Lucky Strike & AT PL120-18 & $37^{\circ} 17.60^{\prime}$ & $32^{\circ} 16.92^{\prime}$ & 1626 & Ophioctenella acies & 9 & V \\
\hline Lucky Strike & AT PL121-19 & $37^{\circ} 17.65^{\prime}$ & $32^{\circ} 16.96^{\prime}$ & 1629 & Ophioctenella acies & 4 & V \\
\hline Lucky Strike & AT ML3-3 & $37^{\circ} 17.54^{\prime}$ & $32^{\circ} 16.40^{\prime}$ & 1630 & O. acies (small postlarva) & 1 & V \\
\hline Rainbow & PI PL1262 & $36^{\circ} 13.73^{\prime}$ & $33^{\circ} 54.13^{\prime}$ & 2292 & Ophioctenella acies & 1 & V \\
\hline Rainbow & PI PL1263 & $36^{\circ} 13.70^{\prime}$ & $33^{\circ} 54.10^{\prime}$ & 2287 & Ophioctenella acies & 1 & V \\
\hline Rainbow-PP29 & PI PL1266 & $36^{\circ} 13.76^{\prime}$ & $33^{\circ} 54.13^{\prime}$ & 2296 & Ophiomitra spinea & 1 & V \\
\hline Near Rainbow & PI PL1266 & $36^{\circ} 13.80^{\prime}$ & $33^{\circ} 54.29^{\prime}$ & 2371 & Ophiomitra spinea & 1 & NV \\
\hline Lucky Strike & PI PL1267 & $37^{\circ} 17.65^{\prime}$ & $32^{\circ} 16.95^{\prime}$ & 1649 & Ophioctenella acies & 1 & $\mathrm{~V}$ \\
\hline Lucky Strike & PI PL1270 & $37^{\circ} 17.37^{\prime}$ & $32^{\circ} 16.51^{\prime}$ & 1707 & Ophioctenella acies & 1 & V \\
\hline \multirow[t]{2}{*}{ Logatchev-Irina 1} & $\mathrm{DE} \# 3665$ & $14^{\circ} 45.15^{\prime}$ & $44^{\circ} 58.75^{\prime}$ & 3014 & Ophioctenella acies & 3 & V \\
\hline & & & & & Ophiura clemens & 1 & V \\
\hline Logatchev-Irina 2 & DE \#3368 & $14^{\circ} 45.19^{\prime}$ & $44^{\circ} 58.76^{\prime}$ & 3020 & Ophioctenella acies & 1 & V \\
\hline Snake Pit & DE \#3673, 3674 & $23^{\circ} 22.90^{\prime}$ & $44^{\circ} 55.80^{\prime}$ & 3490 & Ophioctenella acies & 100 & V \\
\hline Broken Spur & $\mathrm{DE} \# 3676$ & $29^{\circ} 10.00^{\prime}$ & $43^{\circ} 10.00^{\prime}$ & 3030 & Ophioctenella acies & 21 & V \\
\hline \multirow[t]{2}{*}{ Mount Saldanha } & SE PL181-03 & $36^{\circ} 33.67^{\prime}$ & $33^{\circ} 24.92^{\prime}$ & 2325 & Ophiocten centobi & 1 & NV \\
\hline & & $36^{\circ} 33.64^{\prime}$ & $33^{\circ} 24.81^{\prime}$ & 2200 & Ophiacantha crassidens & 1 & NV \\
\hline Near Rainbow & SE PL182-04 & $36^{\circ} 34.60^{\prime}$ & $33^{\circ} 23.60^{\prime}$ & 2837 & Ophiocten centobi & 1 & NV \\
\hline Lucky Strike & SE PL187-09 & $37^{\circ} 17.40^{\prime}$ & $32^{\circ} 16.64^{\prime}$ & 1681 & Ophioctenella acies & 5 & $\mathrm{~V}$ \\
\hline Near Menez Gwen & SE DR01 & $37^{\circ} 50.53^{\prime}$ & $31^{\circ} 31.27^{\prime}$ & 850 & Ophiacantha notata & 1 & NV \\
\hline Near Lucky Strike & VIC PL33 & $37^{\circ} 15.75^{\prime}$ & $32^{\circ} 13.50^{\prime}$ & 1550 & Ophiacantha smitti & 9 & $\mathrm{NV}$ \\
\hline
\end{tabular}

F, Faranaut; DIV1, Divanaut 1; DIV2, Divanaut 2; MI, Microsmoke; MA, Marvel; AT, Atos; PI, Pico; DE, DiversExpedition; SE, Seahma l; VIC, Victor lère. N, number of specimens; V, at hydrothermal vent; NV, not at hydrothermal vent.

Meriadzek Terrace, $47^{\circ} 36^{\prime} \mathrm{N} \quad 08^{\circ} 25^{\prime} \mathrm{W}, 1400 \mathrm{~m}$, with Amphipholis squamata (Delle Chiaje, 1828), Ophiacantha abyssicola G.O. Sars, 1871, Ophiacantha smitti Ljungman, 1872, Ophiothamnus affinis Ljungman, 1872, Ophiolimna bairdi (Lyman, 1883) and Ophiactis abyssicola (M. Sars, 1861), MNHN EcOs 22796; 3 spms, 3.6-4 mm dd, in alcohol, BIOIce Station $2907\left(65^{\circ} 16^{\prime} \mathrm{N} 28^{\circ} 50^{\prime} \mathrm{W}, 1311 \mathrm{~m}\right.$, bottom temperature: $4^{\circ} \mathrm{C}$, salinity: 34.94$)$, NI-1016.

\section{Diagnosis}

Ophioscolex with at least three long, flat, blunt tentacle scales, no disk spines, three smooth arm spines, dorsalmost spine almost two arm segments long, no hook-shaped arm spines. Primary plates indistinguishable in juveniles, disk scales embedded in thick skin in larger animals, dorsal arm plates obvious from third segment, skin thinner on arms than on disk.

\section{Etymology}

From Latin $t r i=$ three, papillatus $=$ with papillae, refers to the three tentacle scales, characteristic of this species.

\section{Description of holotype}

Disk pentagonal, $10 \mathrm{~mm}$ dd, five broken arms, measured with separate fragments included at least twice dd long. Dorsal disk covered with thick skin, torn in the centre 
Table 3. Collecting sites of ophiuroids on cold seeps in the West Atlantic, qualitative collections.

\begin{tabular}{|c|c|c|c|c|c|c|}
\hline Site & Dive & Latitude $\mathrm{N}$ & Longitude W & Depth $(\mathrm{m})$ & Species & $\mathrm{N}$ \\
\hline Orinoco A & DS PL02-3 & $10^{\circ} 20.75^{\prime}$ & $58^{\circ} 51.13^{\prime}$ & 1691 & Ophiacantha longispina sp. nov. & 1 \\
\hline Orinoco B & DS PL10-7 & $10^{\circ} 19.97^{\prime}$ & $58^{\circ} 37.30^{\prime}$ & 1947 & $\begin{array}{l}\text { Ophioctenella acies } \\
\text { Amphiura sp. }\end{array}$ & $\begin{array}{l}1 \\
4\end{array}$ \\
\hline Orinoco B & DS 13-2 & $10^{\circ} 20.90^{\prime}$ & $58^{\circ} 51.26^{\prime}$ & 1654 & Ophioplinthaca chelys & 1 \\
\hline Florida Escarpment & $\begin{array}{l}\text { Alvin } 3635 \\
\quad 3636\end{array}$ & $26^{\circ} 01.8^{\prime}$ & $84^{\circ} 54.9^{\prime}$ & 3288 & Ophioctenella acies & $>400$ \\
\hline Blake Ridge & $\begin{array}{l}\text { Alvin } 3709 \\
\quad 3711,3712\end{array}$ & $32^{\circ} 29.62^{\prime}$ & $76^{\circ} 11.47^{\prime}$ & 2155 & $\begin{array}{l}\text { Ophioctenella acies } \\
\text { Ophienigma spinilimbatum gen. et sp. nov. }\end{array}$ & $\begin{array}{r}>250 \\
38\end{array}$ \\
\hline Atwater Canyon & Alvin 3633 & $27^{\circ} 35.71^{\prime}$ & $88^{\circ} 30.59^{\prime}$ & 1947 & Ophienigma spinilimbatum gen. et sp. nov. & 5 \\
\hline $\begin{array}{l}\text { Mississippi Canyon } \\
885\end{array}$ & USL JSL 3339 & $28^{\circ} 03.70^{\prime}$ & $89^{\circ} 42.60^{\prime}$ & 620 & Amphioplus sp. & 1 \\
\hline Green Canyon 354 & USL JSL 4592 & $27^{\circ} 35.90^{\prime}$ & $91^{\circ} 49.60^{\prime}$ & 500 & Ophiotreta valenciennesi rufescens & 6 \\
\hline Alaminos Canyon & $\begin{array}{l}\text { GoM Alvin } \\
3923\end{array}$ & $26^{\circ} 20^{\prime}$ & $94^{\circ} 35^{\prime}$ & 2210 & Ophienigma spinilimbatum gen. et sp. nov. & 5 \\
\hline Florida Escarpment & $\begin{array}{l}\text { GoM Alvin } \\
\quad 3916\end{array}$ & $25^{\circ} 59^{\prime}$ & $84^{\circ} 56^{\prime}$ & 3300 & Ophienigma spinilimbatum gen. et sp. nov. & 5 \\
\hline
\end{tabular}

N, number of specimens; dive numbers preceded by cruise name; DS, Diapisub; ULS, Upper Louisiana Slope; GoM, Deep Gulf of Mexico.
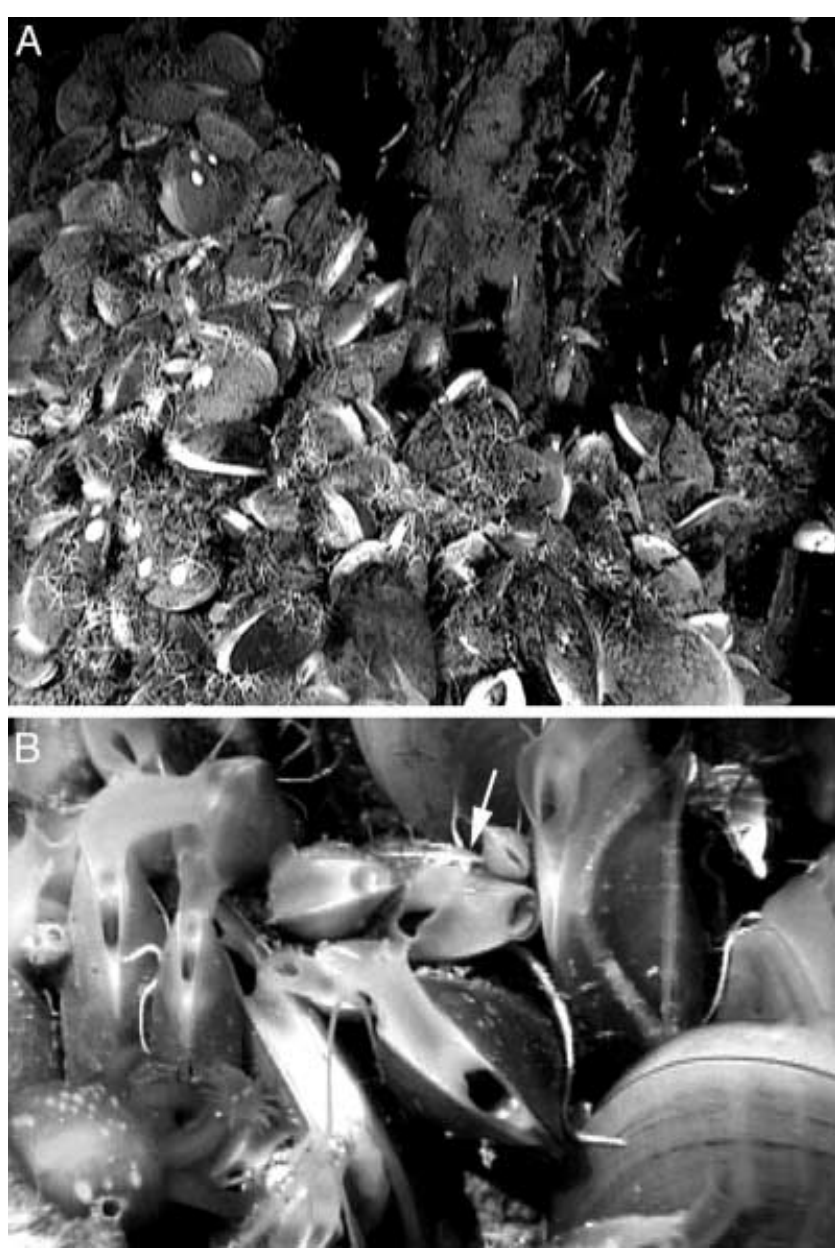

Figure 2. Habitat photographs from video observations: (A) Logatchev (MAR), Bathymodiolus mussels with dense population of Ophioctenella acies; (B) Blake Ridge cold seep (courtesy C. Van Dover), Bathymodiolus mussel bed, arrow indicates a possible Ophienigma spinilimbata gen. et sp. nov.
(Figure 3A), no scales visible externally in wet animal, but embedded in the skin (visible when dried) are thin transparent irregularly shaped overlapping scales with few minute perforations in the centre of the scale and near its edge. The disk scalation extends onto the first three arm segments, obscuring the arm plates (Figure 3B). Dorsal arm plates visible from third segment beyond disk margin, skin thinner on this and following segments, plates about as wide as long, diamond-shaped, acute proximal angle, rounded distal angle, a low longitudinal ridge or keel in the middle, following plates just separate. Lateral arm plates striated, meeting dorsally. Three (on sixth segment sometimes four) flat smooth, tapering, semi-transparent, hollow arm spines, dorsal spine longest, about two arm segments, none of the spines transformed into hooks. Spine articulations round.

Ventral disk covered with skin, obscuring the thin scales. A cluster of two to three pointed spine-like apical papillae, not clearly differentiated from the five to six similar oral papillae on each lateral jaw edge (Figure $3 \mathrm{C}$ ). At the second tentacle pore, situated in the mouth angle, three flat scales with blunt ends arise, separate from the row of oral papillae, two of them twice as long as the tentacle scales on the arm on the adoral shield, the third scale on the first ventral plate about half as long as the others. Oral shield flaring, twice as wide as long, obtuse proximal angle with straight edges, distal edge projecting slightly in the middle. Adoral shields narrow, wing-like, pairs do not touch above oral shield, distal end slightly wider than proximal end, not extending around the distal angles of the oral shield (Figure 3G). Ventral arm plate twice as long as wide, lateral edges deeply concave at tentacle pore, distal edge twice as wide as proximal edge, both convex, adjacent plates slightly overlapping (Figure 3D). Three to four (on some pores five) long flat tentacle scales with blunt ends, one of them on the edge of the ventral plate, the others on the lateral plate. Colour alive unknown, in alcohol brownish rosé, with stains of rust-coloured sediment. 

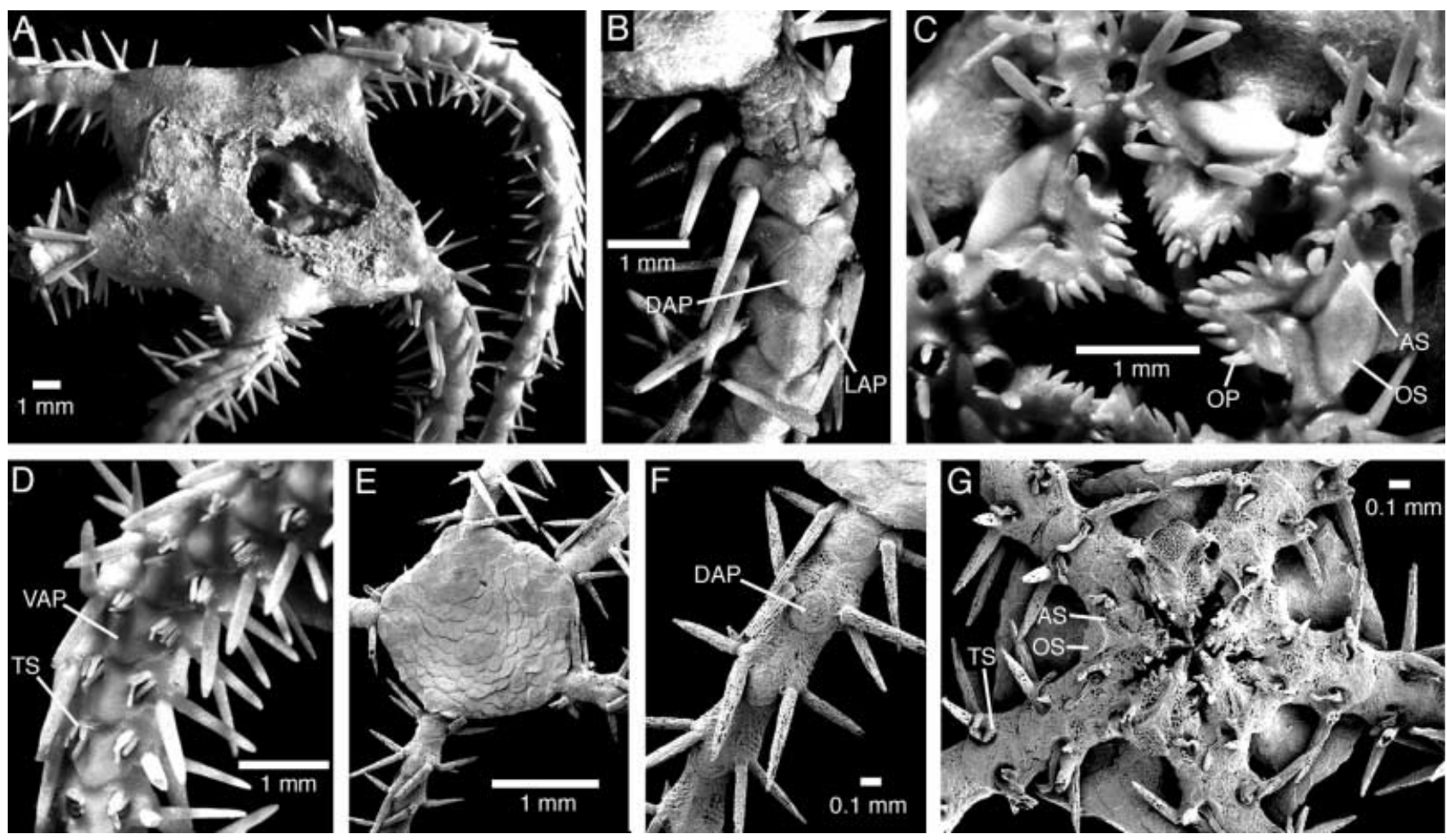

Figure 3. Ophioscolex tripapillatus sp. nov. (A-D) Holotype: (A) dorsal overview, disk surface torn; (B) dorsal arm plates proximally; (C) ventral aspect; (D) ventral arm proximally with numerous tentacle scales. (E-G) Paratype, postlarva: (E) dorsal aspect; (F) arm dorsally; (G) ventral aspect. AS, adoral shield; DAP, dorsal arm plate; LAP, lateral arm plate; OP, oral papillae; OS, oral shield; TS, tentacle scale; VAP, ventral arm plate.

\section{Paratype variations}

Three BIOIce specimens with $3.6-4 \mathrm{~mm}$ dd, arms all broken and distal part lost, all skeletal elements present as in holotype, dorsal arm plates wider apart indicating the immature stage of these specimens. Colour alive unknown, in alcohol white. The VITAL specimen (Figure $3 \mathrm{E}-\mathrm{G}$ ) is a postlarva with $2 \mathrm{~mm}$ dd, skin not as thick as in larger specimens, transparent. Dorsal disk formed of uniform large thin round transparent overlapping scales with few small perforations, among which the primary plates are not distinguishable, radial shields can hardly be differentiated from disk scales (Figure 3E). Dorsal arm plates rounded diamond-shaped, wide apart. Three arm spines and a single tentacle scale are present (Figure $3 \mathrm{~F}$ ). Long pointed teeth, shorter, blunt apical papilla and four slightly smaller oral papillae. The oral shield is teardrop-shaped, about as wide as long, with strongly convex distal edge (Figure 3G). Ventral arm plates shaped as in adult, wide apart. This small animal can be associated with the other four by the similar shape of the dorsal disk scales, dorsal and ventral arm plates and shape and number of spines. It is different from the postlarvae of both other species of Ophioscolex, O. glacialis Müller \& Troschel, 1842 and O. purpureus Düben \& Koren, 1846 known from the North Atlantic (S. Stöhr, unpublished results).

\section{Remarks}

The genus Ophioscolex shares many characters, such as the thick skin, the disk scalation, the elongated jaw, the superficial position of the second tentacle pore and the shape of the oral papillae, with the ophiacanthid subfamily Ophiotominae Paterson, 1986. Mortensen
(1933) suggested the subgenus Ophiolycus for species of Ophioscolex with hook-shaped arm spines, tentacle scales and the second tentacle pore positioned in the mouth slit. Among North Atlantic species Ophioscolex purpureus falls into that subgenus. Ophioscolex glacialis, O. corynetes (H.L. Clark, 1911) and O. inermis Mortensen, 1933 lack hooks, forming Mortensen's remaining subgenus Ophioscolex. Paterson (1986) distinguished Ophioscolex from Ophiotominae, because its arm spine articulation is not commashaped and because of the presence of hook-shaped distal dorsal arm spines. The new species does not have a comma-shaped spine articulation, but it lacks hooks and seems to fall within Ophiolycus because of the presence of tentacle scales and the deeply set second tentacle pore. Also, species within Ophiolycus seem to have stronger dorsal arm plates, which appear to be either lacking (Ophioscolex glacialis) or delicate (Ophioscolex inermis) in species of Ophioscolex (Ophioscolex). The lack of arm hooks may place Ophioscolex tripapillatus within the Ophiotominae, but it is doubtful whether the shape of the arm spines is a valid family specific character and most Ophiotominae bear disk spines or granules, whereas O. tripapillatus does not. Ophioscolex and Ophiotominae are distinguished by few characters, but pending a revision we propose to place the new species within Ophioscolex.

The five specimens of Ophioscolex tripapillatus were found in three widely separate localities in the north-eastern Atlantic Ocean in depths below $1000 \mathrm{~m}$. Among 350 individuals of Ophioscolex so far found in 33 of over 200 examined BIOIce samples, only the three specimens of $O$. tripapillatus described here were found (S. Stöhr, unpublished results). It thus appears to be a rare species with wide distribution. 
Suborder OPHIURINA Müller \& Troschel, 1840

Family OPHiACANTHidAe $s . l$. Perrier, 1891

Genus Ophienigma gen. nov.

Diagnosis

As type species.

Etymology

From Latin ophi=from ophiuroid and Greek enigma= riddle, because the species has affinities with many taxa and shows an unusual combination of characters. Gender neuter.

\section{Type species}

Ophienigma spinilimbatum sp. nov.

Description

As type species.

\section{Ophienigma spinilimbatum sp. nov.} (Figure 4)

Holotype

7.6 mm dd, gold-coated for SEM, USNM 1026303.
Type locality

'Alvin' dive 3709, 25 September 2001, Blake Ridge off South Carolina, $32^{\circ} 29.623^{\prime} \mathrm{N} \quad 76^{\circ} 11.467^{\prime} \mathrm{W}, \quad 2155 \mathrm{~m}$. Collected by the cruise ODP Site 996, among mussels Bathymodiolus aff. boomerang Cosel \& Olu, 1998 and Bathymodiolus heckerae Gustafson et al., 1998; the accompanying fauna includes chaetopterid polychaetes, cake urchins Sarsiaster griegii, chiridotid holothurians and shrimps Alvinocaris spp. (Van Dover et al., 2003).

\section{Paratypes}

One spm, $8.8 \mathrm{~mm}$ dd, dried on aluminium stub, goldcoated for SEM, from type locality, SMNH-Type-5971; remaining 37 spms 5-8.8 mm dd, SMNH-Type-5972 (15 spms), USNM 1026304 (15 spms), LACM 2001-018.001 (7 spms), from type locality, dives pooled.

\section{Other material examined}

Five spms, 'Alvin' dive 3633 (Table 3), soft sediment, mussels, bacterial mats, holothuroids, echinoids, asteroids, sponges, anemones, snails, non-vent fish; 5 spms, Alaminos Canyon, sample A3923 (Table 3), collected in
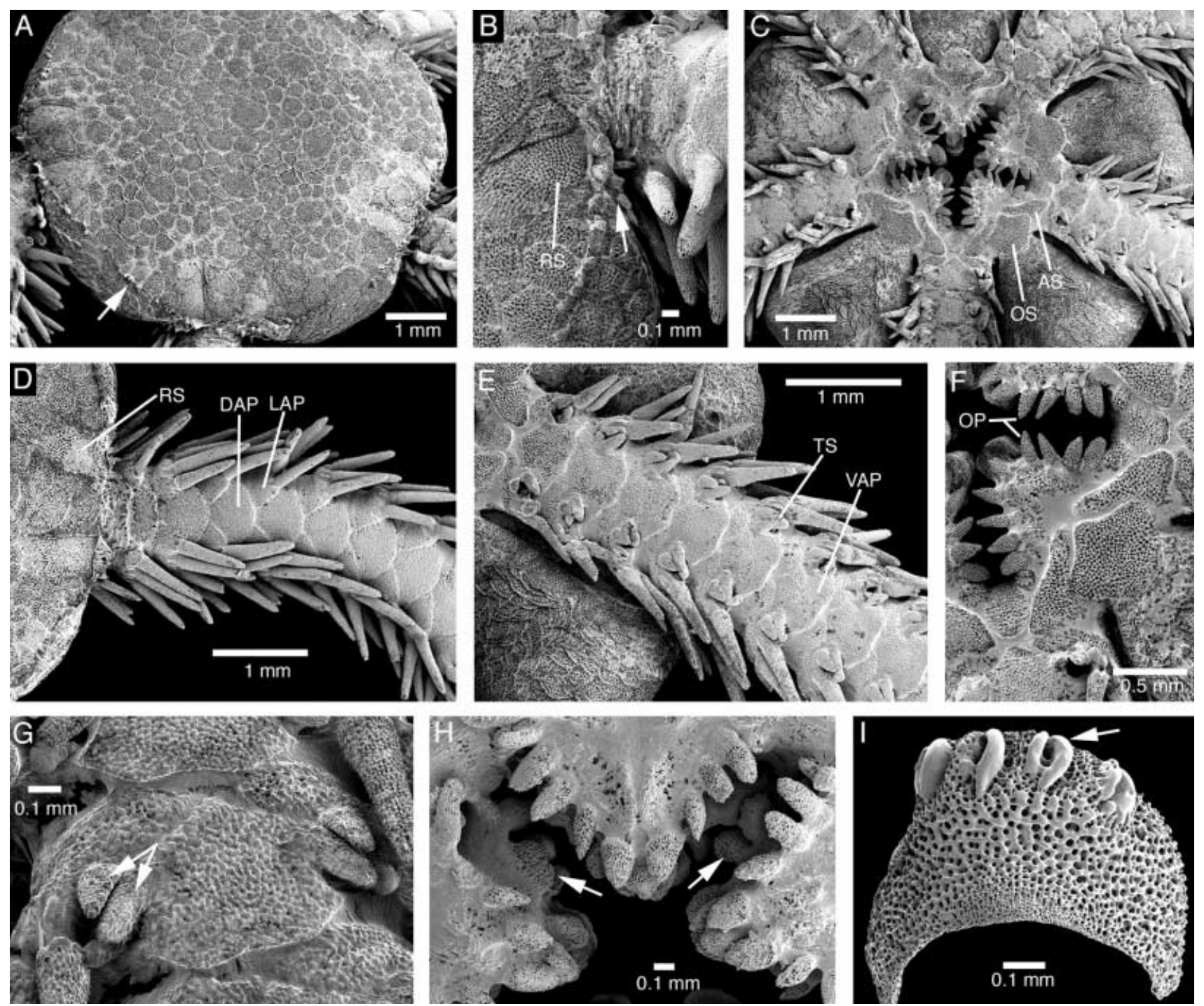

Figure 4. Ophienigma spinilimbatum gen. nov. sp. nov. (A-G) Holotype: (A) dorsal disk with fringe of papillae (arrow); (B) arm combs (arrow), radial shield and first dorsal arm plates; (C) ventral aspect; (D) arm dorsally; (E) arm ventrally; (F) oral plates and papillae; (G) tentacle scales (arrows). (H) Paratype, jaw with additional papillae deep in oral cleft (arrows); (I) the arm spine articulation (arrow) is not comma-shaped. Abbreviations as in Figure 3. 
tubeworm aggregations, adjacent to mussel beds; 5 spms, Florida Escarpment, sample A3916 (Table 3), collected among tubeworms, with mussels nearby.

\section{Etymology}

From Latin spina $=$ spine and limbatus=bordered, referring to the fringe of spines bordering the disk.

\section{Diagnosis}

Species of Ophiacanthidae with sharp border between dorsal and ventral disk, bearing short conical spines, forming 'arm comb'-like clusters at arm base, radial shields separate, arm spines erect, about an arm segment long. Single pointed apical papilla, four similar oral papillae to each jaw edge, two tentacle scales.

\section{Description of holotype}

Disk round, slightly inflated, flexible, $7.6 \mathrm{~mm} \mathrm{dd}$, five broken arms, at least four times dd. Primary plates distinguishable as larger round plates among smaller round imbricating scales (Figure 4A). Distinct border between dorsal and ventral disk, ventral scales smaller, visible from above in interradii. Border bears a fringe of low conical spines, continuing across arm base, several spines lateral of arm base bearing similarity to an 'arm comb' (Figure 4B). Radial shields about 1/10 of dd in length, oval, twice as long as wide, widely separated by several overlapping disk scales (Figure 4D).

Dorsal arm plates fan-shaped from fourth segment, twice as wide as long, convex distal edge, acute proximal angle, following plates contiguous (Figure 4D). First two dorsal arm plates reduced to short overlapping bands across the arm, but not forming a wedge between the radial shields, third plate half as long as following plates (Figure 4B \& D). Up to five equal, smooth arm spines, slightly longer than an arm segment, erect on pronounced articulation ridge.

Ventral scales strongly overlapping, in bulging parts almost standing vertically on edge, full size visible only at bursal edge (Figure 4G \& E). Jaws bear 1-2 slender pointed apical papillae, block-like teeth, twice as wide as apical papillae, four flat, pointed oral papillae along each lateral jaw edge, distally increasing in width (Figure 4F). Second tentacle pore inside mouth slit, bearing two low wide scales, one on oral plate, a smaller one on adoral shield. Adoral shields flaring, extending around lateral angles of oral shield. Oral shield pentagonal, strongly convex distal and lateral edges, proximal edges slightly concave, shorter than $1 / 8 \mathrm{dd}$. Two flat tentacle scales on all pores, parallel to each other with straight inner and convex outer edge, a slightly shorter one arising from the lateral plate and a longer one from the ventral plate (Figure 4G). Ventral arm plate pentagonal, wider distally than proximally, slightly wider than long, adjacent plates contiguous, concave notch in distal edge, concave lateral edges, obtuse proximal angle (Figure 4E). Bursal slit extends from oral frame to disk edge, no genital papillae (Figure 4G). Colour in alcohol, cream.

\section{Paratype variations}

Size range $5-8.8 \mathrm{~mm}$ dd. Primary plates in largest animals often less obvious than in holotype, spine fringe often rubbed off except for a few spines near radial shields. Interradial disk often bulging, longest arms over six times dd. Mouth papillae variable in number, particularly deep in the mouth lateral projections on the jaws are common (Figure 4H). Apical papilla often deeper in mouth opening than oral papillae, causing first lateral pair to meet. Teeth twice as wide as apical papilla, sometimes multicuspid. Colour in alcohol, light orange to cream.

\section{Remarks}

At first glance, the 'arm comb'-like row of spines and the smooth erect arm spines seem similar to Ophiocten, while the oral papillae, dorsal and ventral arm plates are reminiscent of Ophiura. However, the position of the second tentacle pore deep in the mouth angle excludes the family Ophiuridae. The placement of the two tentacle scales, one on the ventral plate and one on the lateral plate, suggests that this may be an Ophiacanthidae or an Amphiuridae. The shape of the jaw and oral papillae suggest that Ophienigma spinilimbatum belongs in the family Ophiacanthidae. The arm plates and spines bear similarities with the ophiacanthid subfamily Ophioplinthacinae Paterson, 1985, e.g. the genus Ophiomitra Lyman, 1869, but the radial shields are smaller than in the taxa within Ophioplinthacinae. In the subfamily Ophiacanthinae Paterson, 1985, radial shields are often small, but usually bar-shaped and the adoral shields do not extend around the angles of the oral shield. The absence of commashaped arm spine articulations has been suggested to separate the subfamily Ophiohelinae Paterson, 1985 from the remaining Ophiacanthidae (Paterson, 1985). In the new species slightly curved parallel ridges form the spine articulations (Figure 4I), but it does not fit with the other diagnostic characters of Ophiohelinae, such as a sac-like disk without radial shields and the shape and number of oral papillae and arm spines. Apart from Ophiohelinae, articulations like this are found in Amphiuridae and Ophiactidae (S. Stöhr, unpublished observation). The shape of the swollen disk lying above the arms and the smooth tapering arm spines are similar to Amphiuridae, but there are no paired infradental papillae on the jaw, although in some individuals the uppermost tooth retreats into the mouth and two lateral papillae move closer together in a fashion similar to infradentals. However, there is no buccal scale as in Amphiuridae and the teeth are not tricuspid as in Ophiactidae. The ontogeny of the skeleton needs to be studied to shed more light on the taxonomic relationships of this species, but until juvenile stages are available, placement with Ophiacanthidae seems best supported by the evidence.

The species was found at four cold seep sites, in greater numbers than any other ophiuroid species in reducing environments, with the exception of Ophioctenella acies, and appears to be restricted to this kind of habitat. It occurs sympatrically with $O$. acies, although less abundant, at Blake Ridge, on Bathymodiolus mussel beds. Bottom water-temperatures at the site were $3.2^{\circ} \mathrm{C}$ and bacterial mats were observed mainly on the soft sea-floor sediments, but also on the mussels (Van Dover et al., 2003).

Subfamily OPHIACANTHINAE Paterson, 1986

Genus Ophiacantha Müller \& Troschel, 1842 Ophiacantha longispina sp. nov.

Holotype (Figure 5)

$4.5 \mathrm{~mm} \mathrm{dd}$, dried, mounted on aluminium stub, goldcoated for SEM, MNHN EcOs 22797. 

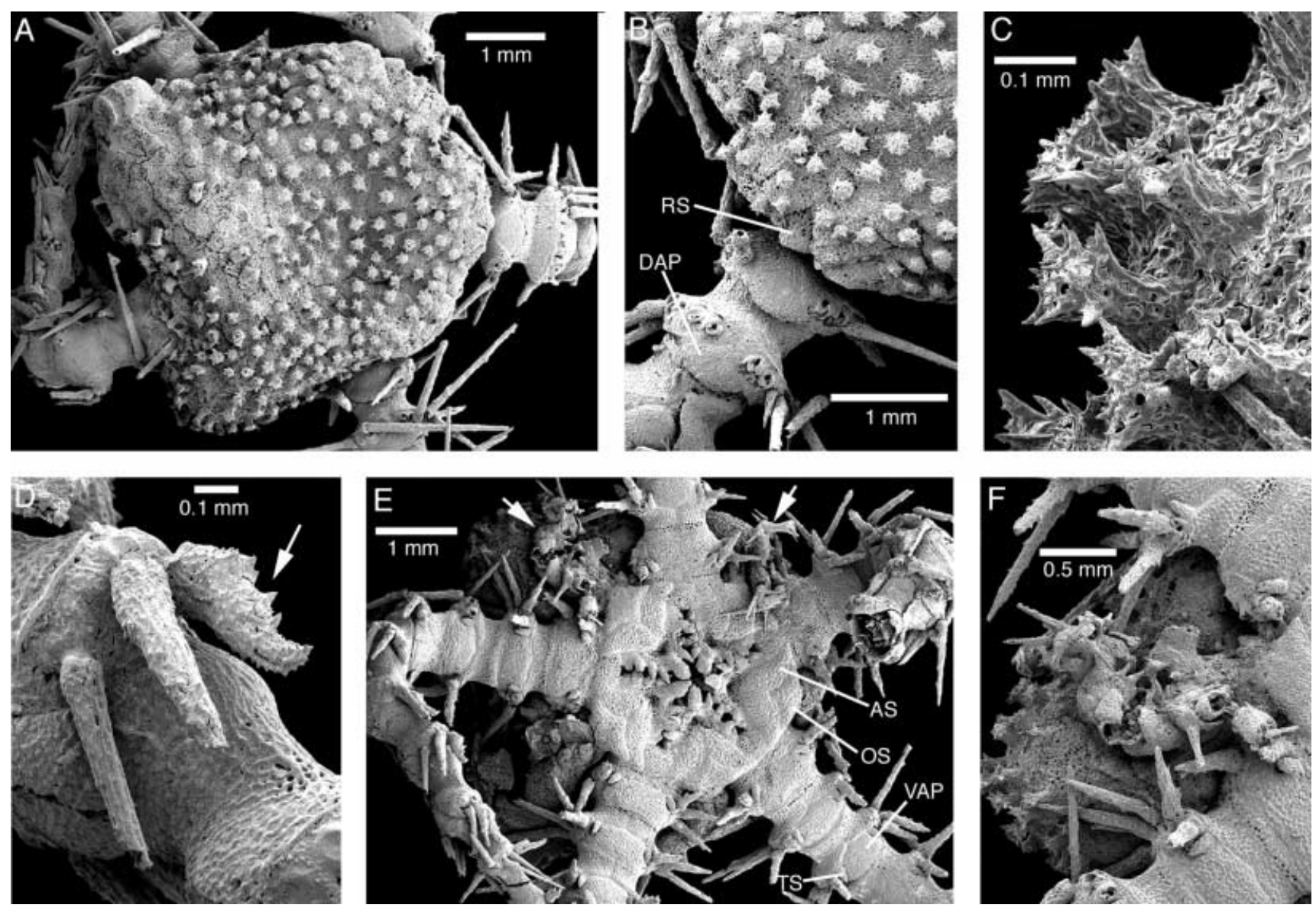

Figure 5. Ophiacantha longispina sp. nov., holotype: (A) dorsal aspect; (B) radial shields and dorsal arm plates; (C) dorsal disk spines; (D) spines on mid-section of arm, lowest spine hook-shaped; (E) ventral aspect, one interradius torn, juveniles emerging in two other interradii, indicated with arrows; (F) emerging juvenile. RS, radial shields; other abbreviations as in Figure 3.

\section{Type locality}

DIAPISUB, DS02-3, 25 December 1992, south of Barbados, Orinoco A, $10^{\circ} 20.75^{\prime} \mathrm{N} 58^{\circ} 51.13^{\prime} \mathrm{W}, 1691 \mathrm{~m}$; collected at the base of a small carbonated and extinct chimney, with sponges, scleractinian, and bivalve shells, indicating past activity at this place.

\section{Etymology}

From Latin longus=long and spina $=$ spine.

\section{Diagnosis}

Viviparous Ophiacantha with five arm spines, the dorsalmost 1.5 times as long as an arm segment. Distally three spines, ventralmost hook-shaped. Disk spines with short multifid crown, visible part of radial shields same size as disk scales, separate. Four pointed oral papillae, distalmost one smaller than other three. Ventral arm plate rectangular with wide proximal angle, straight distal edge, adjacent plates widely separate. Beaded structure of oral and adoral shields.

\section{Description of holotype}

Disk high and bulging, $4.5 \mathrm{~mm}$ dd, with short robust spines with wide multifid crown, $0.22 \mathrm{~mm}$ long, partially obscuring disk scales, viviparous (Figure 5A \& G). Scales round, imbricating, largely covering the radial shields, the visible distal part about the same size as the disk scales, as twice as long bar-like part underlying the scales, pairs widely separated by a wedge of scales (Figure 5B). Five broken arms, at least three times dd in length, strongly noded, with five rough spines not quite forming a fan above the proximal arm, uppermost one as long as 1.5 segments, ventralmost one half as long, on distal segments three spines, from sixth segment on ventralmost one hookshaped (Figure 5D). Dorsal arm plate fan-shaped, convex distal edge, acute proximal angle, straight lateral edges, twice as wide as long, adjacent plates widely separate (Figure 5B). Lateral arm plates meeting both dorsally and ventrally, with pronounced articulation ridge (Figure 5D).

Ventral disk with round imbricating scales, at disk edge bearing spines, one interradius ruptured, two others with emerging young, which appear to be breaking through the disk wall rather than crawling out of the bursal slits (Figure 5E,F). Apical papilla larger than oral papillae, pointed. Three to four spine-like to rounded oral papillae along each jaw edge, distalmost one smaller than others (Figure 5E). Oral shield twice as wide as long, with winglike lateral sides, pointed proximal angle, convex distal edge. Adoral shields almost as wide as oral shield, curving along the proximal edges of the oral shield, with strongly convex nearly angular distal edge, weakly concave proximal edge, meeting above, not curving around the lateral angles of oral shield (Figure 5E). Oral and adoral shields have a glassy beaded structure. Ventral arm plates twice as wide as long, almost rectangular, with 
wide obtuse proximal angle, straight distal edge, concave lateral edges, widely separate from each other. Single pointed oval tentacle scale.

\section{Remarks}

The small radial shields at first suggest that this species may belong in the genus Ophiomitrella Verrill, 1899, but after treatment of the dry gold coated animal with bleach on one radius, the disk scales could be removed revealing a long bar-like radial shield, which is typical for Ophiacantha (Paterson, 1985). Viviparity is not uncommon in the genus. Ophiacantha vivipara Ljungman, 1870 and O. anomala G.O. Sars, 1872 are six-armed. Ophiacantha marsupialis Lyman, 1875 has five spine-like oral papillae, two distal ones longer, its disk spines are pointed and it has only three arm spines. Ophiacantha densispina Mortensen, 1936 is with $16 \mathrm{~mm}$ dd more than three times as large as O. longispina, has long slender oral papillae, ventral arm plates with convex distal edge and smooth pointed arm spines 1$1.5 \mathrm{~mm}$ long. Both have been found above $500 \mathrm{~m}$ depth. The relatively thin, strongly noded arms distinguish O. longispina from most non-viviparous species. There is a strong similarity with O. renekoehleri (Koehler, 1904) (=Ophiomitrella moniliformis; see O'Hara \& Stöhr, in press), which is of about the same size, with thin strongly noded arms, but with granules on the disk and adoral shields extending around the lateral angles of the oral shield. The similar Ophiacantha richeri O'Hara \& Stöhr (in press) has slender disk spines with long sharp points. Ophiacantha pentagona Koehler, 1897 and O. serrata Lyman, 1878 have strongly noded arms and adoral shields not extending around the lateral angles of the oral shield, but both have shorter disk spines with distinct points and more than five arm spines (O'Hara \& Stöhr, in press). Among the North Atlantic deep-sea species (Paterson, 1985), O. lineata Koehler, 1896, O. metallacta H.L. Clark, 1915 and O. notata Koehler, 1906 have similar disk spines and adoral shields, but seven to eight arm spines and contiguous, distally convex ventral arm plates. The distal hookshaped arm spine further distinguishes O. longispina from all other species. Ophiacantha is ill-defined (O'Hara \& Stöhr, in press), but until it is revised we propose placement of the new species in this genus.

The ruptured disk is most likely an artefact of preservation as we know of no species which releases its young in that way. More specimens are needed to answer this question.

\section{Ophiacantha enopla veterna (Koehler, 1907)}

\section{Material examined}

One spm, $10 \mathrm{~mm}$ dd, on SEM stub, gold-coated, $1 \mathrm{spm}$, $7.4 \mathrm{~mm}$ dd, in alcohol, MARVEL, PL1199-10, box 1 (Table 2 ), collected on the wall of the MAR axial valley, among diverse fixed fauna: sponges, hydrozoa, gorgonarian Iridogorgia Verrill, 1883, colonial tunicates, sympatric with single Asteroschema inornatum.

\section{Remarks}

Both animals have only seven arm spines in contrast to the nine spines typical for this species (Paterson, 1985). Distally, two ventral spines become hook-shaped. The tiny spine-like tentacle scale is present throughout the arms. Except for these small differences, the specimens are as described by Paterson (1985). They were found on the MAR in non-vent conditions, which is the westernmost locality recorded so far and slightly deeper than its previous greatest depth of $2245 \mathrm{~m}$ (Paterson, 1985).

\section{Genus Ophiotreta Verrill, 1899}

Ophiotreta valenciennesi rufescens Koehler, 1896

\section{Material examined}

One spm, in alcohol, DIVANAUT 1, PL 906-14, box 1 (Table 2), collected on a whitish sulphide block sampled at about a metre off the base of a cylindrical edifice emitting a strong hydrothermal, translucent flow at $296^{\circ} \mathrm{C}$, next to a cluster of mussels Bathymodiolus azoricus Cosel et al., 1999 set on a diffusing area (fluids emitted from substratum cracks). This block was covered with sponges, hydrozoa Grammaria abietina (Sars, 1851), serpulid polychaetes; no megafauna visible, except dead coral; 5 spms, Green Canyon (Table 3), sample 4592, collected among Lophelia corals, very abundant.

\section{Remarks}

This species was previously known from off Madeira south to Angola at depths of 640-1440m (Paterson, 1985). Menez Gwen is a more northern and western location and the animal clearly lived in an area influenced by vent conditions. It is one of two ophiuroid species found at this site (see below), where Ophioctenella acies is absent. Its discovery in seeps in the Gulf of Mexico is surprising as it is the first record from the West Atlantic. The collection notes only record the species as 'very abundant', but no quantitative samples were taken. The ophiuroids appear to be associated with Lophelia corals.

\section{Genus Ophiomitra Lyman, 1869 \\ Ophiomitra spinea Verrill, 1885}

\section{Material examined}

One spm, $8 \mathrm{~mm}$ dd, PICO, Rainbow-PP29, box 4 (Table 2), collected in oxidized sediment, $2 \mathrm{~m}$ down the base of the active chimney complex, among mussel shells, with one live mussel fixed on a sulphide block, one shrimp Mirocaris fortunata (Martin \& Christiansen, 1995) and chaetopterid polychaetes; $1 \mathrm{spm}, 14 \mathrm{~mm} \mathrm{dd}$, PICO, same dive, near Rainbow (Table 2), collected on a wall $400 \mathrm{~m}$ west of the Rainbow hydrothermal vent field, thus markedly outside of hydrothermal influence, among sessile fauna: sponges, hydrozoa, coral Desmophyllum cristagalli Milne-Edwards \& Haime, 1848, comatulid, asteroid Freyella sp. Perrier, 1885, at the base of a gorgonarian.

\section{Remarks}

According to Paterson (1985), Ophiomitra spinea can be distinguished from the closely related Ophiomitra hamula Mortensen, 1933 by its high, indented disk, larger, contiguous radial shields, trifid or slightly rugose disk spines with broad base, rounded oral papillae, sunken jaw and less wing-like adoral shields. However, of $O$. hamula only the holotype is known. The larger of the specimens found in this study is of the same size as stated by Paterson (1985) and shows intermediate character states between both species: the disk is weakly 
indented interradially and the radial shields are as large as in $O$. spinea, but separated by a wedge of plates except at their distal edge as in $O$. hamula; the disk granules have a wide base and a conical shape with rough crown as in $O$. spinea, while the oral papillae are flat and tapering with a pointed tip, which resembles $O$. hamula. The smaller individual is of the same size as the holotype of $O$. hamula, is not indented interradially, the disk granules have a wide multifid crown, the radial shields are small, confined to the disk edge and separate, and the oral papillae are spine-like. Thus, the small individual may be identified as O. hamula, while the large animal shows more traits of O. spinea. Still, both individuals are quite similar and the character states of the smaller specimen seem juvenile rather than those of a different species. Particularly, disk granules in ophiacanthids are often abraded in older animals and may assume a strikingly different shape in adults than in juveniles, but many other skeletal elements attain their final shape quite late in ophiuroid ontogeny (Sumida et al., 1998). We conclude that O. spinea and $O$. hamula probably are different ontogenetic stages of the same species, but more material is needed to confirm this.

Ophiomitra spinea has previously been recorded from both sides of the Atlantic, off Martha's Vineyard in the west and the Bay of Biscay in the east (Paterson, 1985), and its occurrence on the MAR is therefore not surprising. Although it was collected at the temperature of the surrounding water $\left(3.2^{\circ} \mathrm{C}\right)$, it appears to be able to live under the influence of vent conditions.

\section{Family OPHIURIDAE Lyman, 1865 \\ Subfamily OPHIURINAE Lyman, 1865 \\ Genus Ophiura Lamarck, 1801 \\ Ophiura (Ophioglypha) clemens (Koehler, 1904)}

Material examined

One spm, $4.4 \mathrm{~mm}$ dd, in alcohol, DiversExpedition, dive 3665 (Table 2), sympatric with Ophioctenella acies.

\section{Remarks}

The arm segments are quite long in this individual and the arm combs do not extend across the arm base, indicating a juvenile stage. The maximum size of this species is $8 \mathrm{~mm}$ dd (Paterson, 1985). The shape and size of most skeletal elements are not fully developed, leading to some uncertainty with its identity, because Ophiura nitida Mortensen, 1933 and Ophiura violainae (Cherbonnier \& Sibuet, 1972) closely resemble Ophiura clemens. However, the shape of the block-like oral papillae and of the oral shield as well as the absence of a raised boss on the central disk plate indicate this specimen is more similar to Ophiura clemens than the other two species. The specimen differs from $O$. clemens as it has only two arm spines instead of three on most segments, none of which is hook-shaped, but this may be due to its immature stage. In the North Atlantic it has been recorded from the Bay of Biscay at $1916 \mathrm{~m}$, but is also known from off the Philippines and East Indies (Paterson, 1985). In the Pacific, O. jejuna (Lyman, 1878) is similar, possibly identical with O.clemens.

This sample comes from a slurping of hydrothermal sediment located within a few metres of a black smoker, where no fauna was visible, and containing small nonhydrothermal peracarid species. However, the presence also of three individuals of Ophioctenella acies at this spot indicates an environment under hydrothermal influence.

\section{Genus Ophiophyllum Lyman, 1878 Ophiophyllum atlanticum sp. nov.} (Figure 6)

\section{Holotype}

$6 \mathrm{~mm}$ dd, in alcohol, skeletal elements on SEM stub, gold-coated, MNHN EcOh 7001.

\section{Type locality}

FARANAUT dive FR23, $\quad 1^{\circ} 36.54^{\prime} \mathrm{N} \quad 46^{\circ} 35.29^{\prime} \mathrm{W}$, $4078 \mathrm{~m}$, in the centre of the axial MAR valley, in the sediment, with a sedentary polychaete.

\section{Diagnosis}

Ophiophyllum with dimorphic arm spines, proximally a ventral paddle-shaped spine and a short pointed one, distally two pointed spines and a middle hook-shaped one. Spine-like apical papillae, round oral papillae. Primary plates not conspicuous. Short bursal slit.

\section{Description}

Disk round, $6 \mathrm{~mm}$ dd, slightly domed dorsally, surface with complex plate structure, rough, five arms (Figure $6 \mathrm{~A} \& \mathrm{I})$. A fringe of small, round, flat scales along sharp disk edge. Animal covered with thin skin. Centre of disk with small irregular, rough scales, primary plates not apparent, radial shields oval, longer than wide, about $1 / 4$ of dd, separated entirely by larger elongated scales (Figure $6 \mathrm{~A})$, a smaller square inner plate and a larger trapezoid outer plate in interradius. Arms all broken off, one piece including part of the disk edge, at least two times dd, dorsally arched, ventrally concave. Proximally two arm spines, ventral spine flat, paddle-like (Figure 6A,F,G), transparent, with longitudinal ridges, oriented downwards with concave ventral side, dorsal spine shorter, pointed tapering, serrated edges (Figure 6A \& H). Distalwards, the paddle-like spine becomes more and more pointed conical, a third short pointed spine appears, on the distalmost segments the middle spine is hook-shaped with a terminal tooth and 1-2 shorter lateral teeth (not figured). Spine articulations difficult to notice, the lower one twice the size of the upper, proximal semicircular ridges opening distally (Figure 6D,E). Dorsal arm plate triangular, twice as long as wide, rough surface, straight lateral edges, convex distal edge (Figure 6A \& $\mathrm{K}$ ). Lateral arm plates cover the larger part of the dorsal and ventral arm, sharp ridge marking the border between ventral and dorsal surfaces, striated dorsally (Figure 6A,C,D). Ventral disk slightly concave, scales rounded, slightly overlapping, smooth (Figure 6B). Ventral arm plate 1.5 times as long as wide, concave lateral edges, straight proximal angle, convex distal edge (Figure $6 \mathrm{~B} \& \mathrm{~J}$ ). Large conspicuous tentacle pores (Figure 6B), second outside mouth slit, third with low minute scale on ventral plate, other pores seem scale-less. Jaw elongated, three spine-like apical papillae, three to four round oral papillae and a wider block-like papilla distally, a papillafree gap half as long as the jaw between apical and oral 

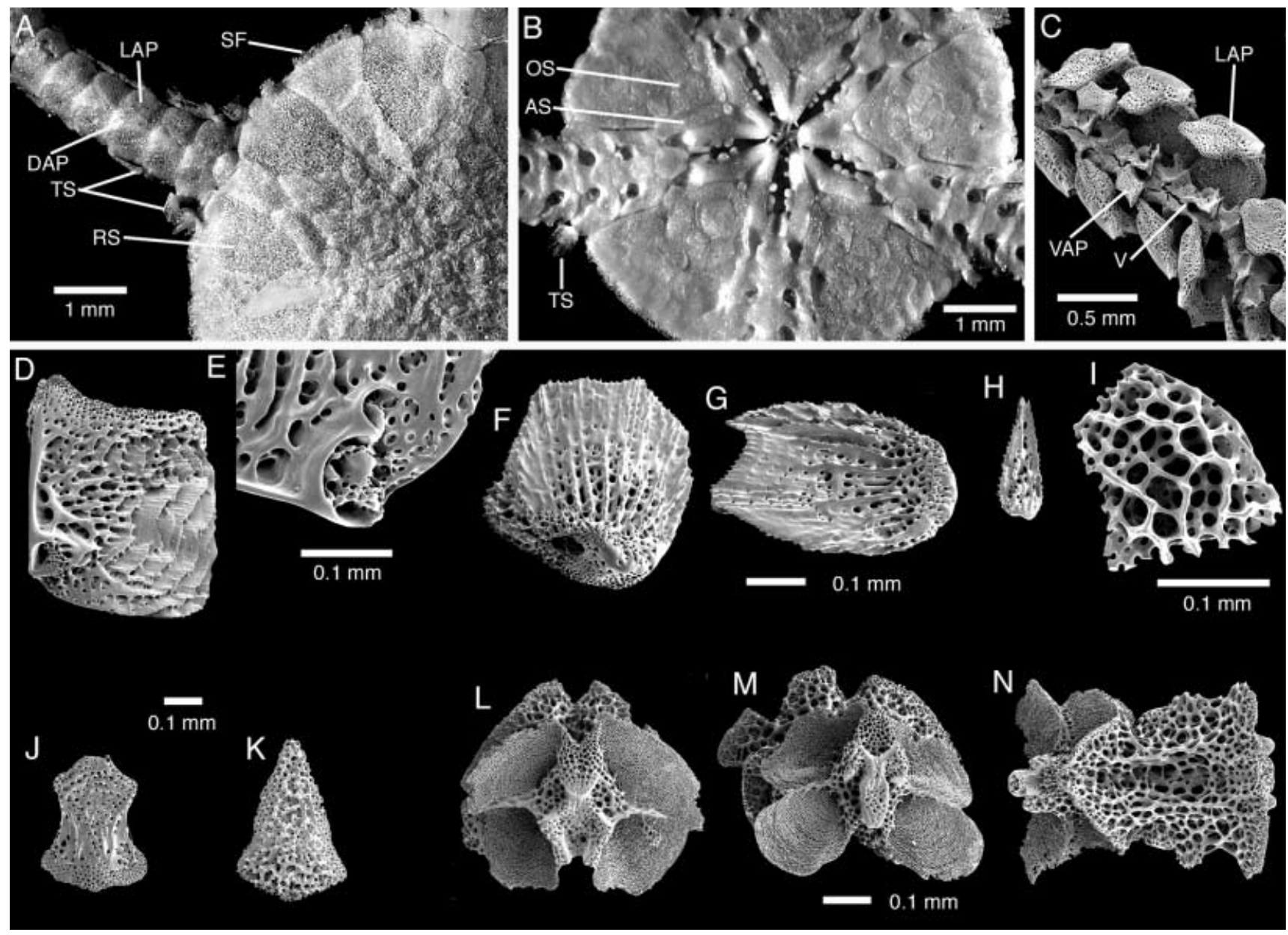

Figure 6. Ophiophyllum atlanticum sp. nov.: (A) dorsal aspect showing scale fringe (SF); (B) ventral aspect; (C) arm skeleton; (D,E) lateral arm plate with two spine articulations; (F,G) concave ventral arm spine; (H) dorsal arm spine; (I) fragment of dorsal disk scale showing a complex rough structure; $(\mathrm{J})$ ventral arm plate; $(\mathrm{K})$ dorsal arm plate; $(\mathrm{L}-\mathrm{N})$ arm vertebrae: $(\mathrm{L})$ proximal face; (M) distal face; (N) dorsal aspect. V, vertebra; other abbreviations as in Figure 3.

papillae (Figure 6B). Adoral shields flaring, extending around lateral angles of oral shield. A small round plate lies proximal to the adoral shields between the oral plates (Figure 6B). Oral shield rounded pentagonal, acute proximal angle, convex distal edge, more or less overlapped by disk scales. Arm vertebra remarkably long, with large muscle attachment surfaces (Figure 6C,L-N), muscle attachment surfaces with 'growth ring'-like structure (Figure 6L,M). The bursal slits extending to second lateral arm plate (Figure 6B). Gonads visible through semitransparent disk. Colour in alcohol, white. All skeletal elements were removed from the proximal part of the arm. The segments under the disk contain shorter vertebrae than shown.

\section{Remarks}

Six species of Ophiophyllum were previously known. Ophiophyllum teplium McKnight, 2003 has dimorphic disc spines and a short bursal slit, but no hooks, tumid disk scales, and an ovoid oral shield. Ophiophyllum novaecaledoniae Vadon, 1991 has a similar paddle-shaped proximal spine, but larger radial shields and conspicuous primary radial plates. Ophiophyllum petilum Lyman, 1878 and O. mariginatum A.H. Clark, 1916 have only a single arm spine, O. borbonica Vadon \& Guille, 1984 has larger dorsal disk plates, a single large interradial plate and square oral papillae. Ophiophyllum atlanticum is the first species of the genus found in the Atlantic Ocean and it has been found at twice the depth of the other species (Vadon, 1991).

\section{Genus Ophiocten Lütken, 1855}

Ophiocten centobi Paterson, Tyler \& Gage, 1982

\section{Material examined}

One spm, in alcohol, DIVANAUT 1, DV 900-08, box 1 (Table 2), on basalt fragment, among mytilid bivalves and pteropod shells, dead coral and basaltic gravel, none or few visible fauna and bioturbation marks; $1 \mathrm{spm}$, SEAHMA-1, PL 181-3, GBT1-3, an area with very few emission flows and no visible emission at the location of the sample; among numerous sponges Cynachira sp.; 1 spm, PL 182-04, GBT1-1, collected in an abyssal environment, with stalked crinoid and Cynachira sponge.

\section{Remarks}

This species was hitherto known only from the type locality in the Bay of Biscay at a depth of $2420 \mathrm{~m}$ (Paterson et al., 1982). All three new records are from the MAR, although only one (DV 900-08) from an old 

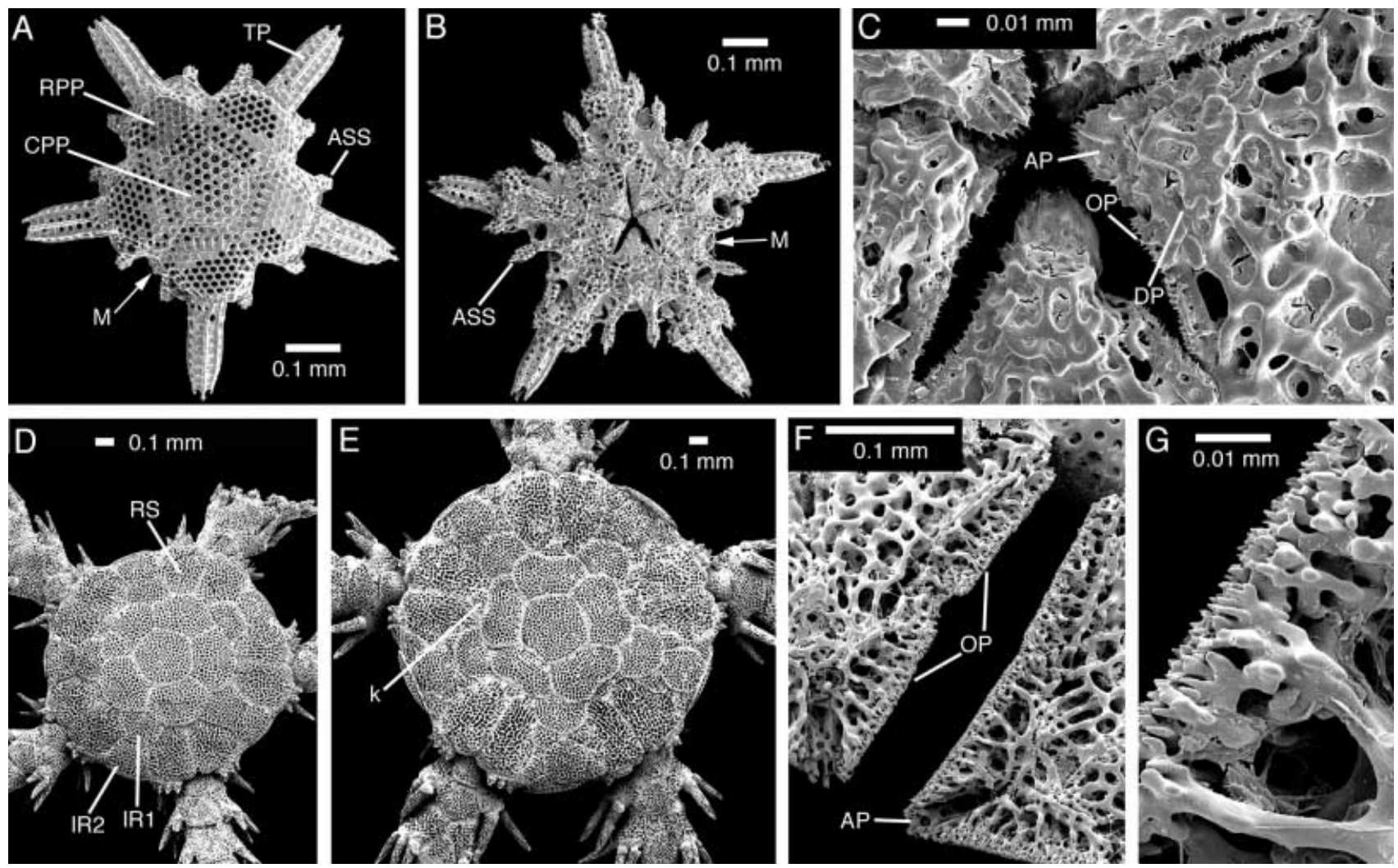

Figure 7. The smallest postlarva $(\mathrm{A}-\mathrm{C})$ of Ophioctenella acies has an apical papilla at the tip of the jaw and a serrated two-part 'blade' along dental and oral plates $(\mathrm{C})$. The arm comb appears at $1.4 \mathrm{~mm} \mathrm{dd}(\mathrm{D})$ and the k-plate at $1.9 \mathrm{~mm}$ dd $(\mathrm{E})$. The oral papilla or 'blade' in adults $(F, G)$ consists of a proximal and a distal part; at the tip of the jaw, beneath adjacent 'blades', the apical papilla is located. The structure of the oral papilla is multilayered rough $(\mathrm{G})$. AC, arm comb; AP, apical papilla; DP, dental plate; k, k-plate; M, madreporite; other abbreviations as in Figure 3.

vent site. The depth range of the species is extended to 1680-2837 m. It was not found at hydrothermal sites.

Genus Ophioctenella Tyler et al., 1995

Ophioctenella acies Tyler et al., 1995

(Figures $2 \& 7$ )

\section{Material examined}

Several hundred specimens from smallest postlarva to adult, in alcohol. MAR (Table 2), Lucky Strike area: on chimneys, among mussels (Bathymodiolus azoricus), covered with filamentous bacteria, in shimmering water diffusing at $10^{\circ} \mathrm{C}$; Logatchev (Figure 2): mainly between mussels (Bathymodiolus puteoserpentis), covering small diffusers, on sulphide rocks covered by Zoantharia, on hydrothermal sediment, among chaetopterid polychaetes, numerous gastropods Phymorhynchus Dall, 1908, siphonostome copepods, acari, tanaids, crabs, shrimps; Rainbow area: in diffusing area, among mussels B. azoricus, polychaetes, pycnogonids; Broken Spur: among mussels B. puteoserpentis Cosel et al., 1994; Snake Pit area: at site Elan among mussels B. puteoserpentis, less at site Le Clou, abundant at site Les Ruches without mussels, with polychaetes Polynoidea, gastropods Phymorhynchus spp., crabs, shrimps; South Barbados, Orinoco B (Table 3), collected in mud, near vestimentiferan Escarpia sp., mussels B. boomerang, gastropods Phymorhynchus aff. alberti, shrimps Alvinocaris muricola Williams, 1988, echiurans, polychaetes, asteroid. Florida Escarpment (Table 3), among mussels B. heckerae and B. brooksi Gustafson et al., 1998, vestimentiferan tubeworms Escarpia laminata Jones, 1985 and Lamellibrachia sp., shrimps A. muricola and galatheid squat lobsters Munidopsis cf. subsquamosa. Blake Ridge (Table 3), on mussel beds, with Ophienigma spinilimbatum.

\section{Description}

The animals conform well to the type description. However, at the site Snake Pit-Elan, the largest animals reach a size of $5 \mathrm{~mm}$ dd, considerably larger than the $3 \mathrm{~mm}$ of the type material. At this size, four spines are present on several proximal arm segments, the dorsalmost one almost twice as long as the lower spines. The samples from Blake Ridge contain animals from newly settled postlarvae $(0.35 \mathrm{~mm}$ dd; Figure $7 \mathrm{~A}, \mathrm{~B})$ to small adults of $3 \mathrm{~mm}$ dd. Unfortunately, in the original description, captions and figures of postlarvae were confused. It therefore seems desirable to present correct pictures of the young stages and to amend the description. Tyler et al. (1995) interpreted the oral papillae of Ophioctenella acies as a continuous 'blade' running along the jaw edges, with no apical papilla. Closer inspection of the jaw skeleton of larger specimens, however, reveals an apical gap between both lateral 'blades' beneath which the apical with papilla (=tooth) can be seen, about as wide as long, blunt, with serrated edge (Figure 7F). It is already visible in the smallest postlarvae, as is the dental plate distal to it (Figure 7A-C). The lateral 'blade' has been compared with the buccal scale (Tyler et al., 1995), which develops early in most ophiuroids and in Ophiuridae later seems to divide to form the oral papillae (Sumida et al., 1998; 

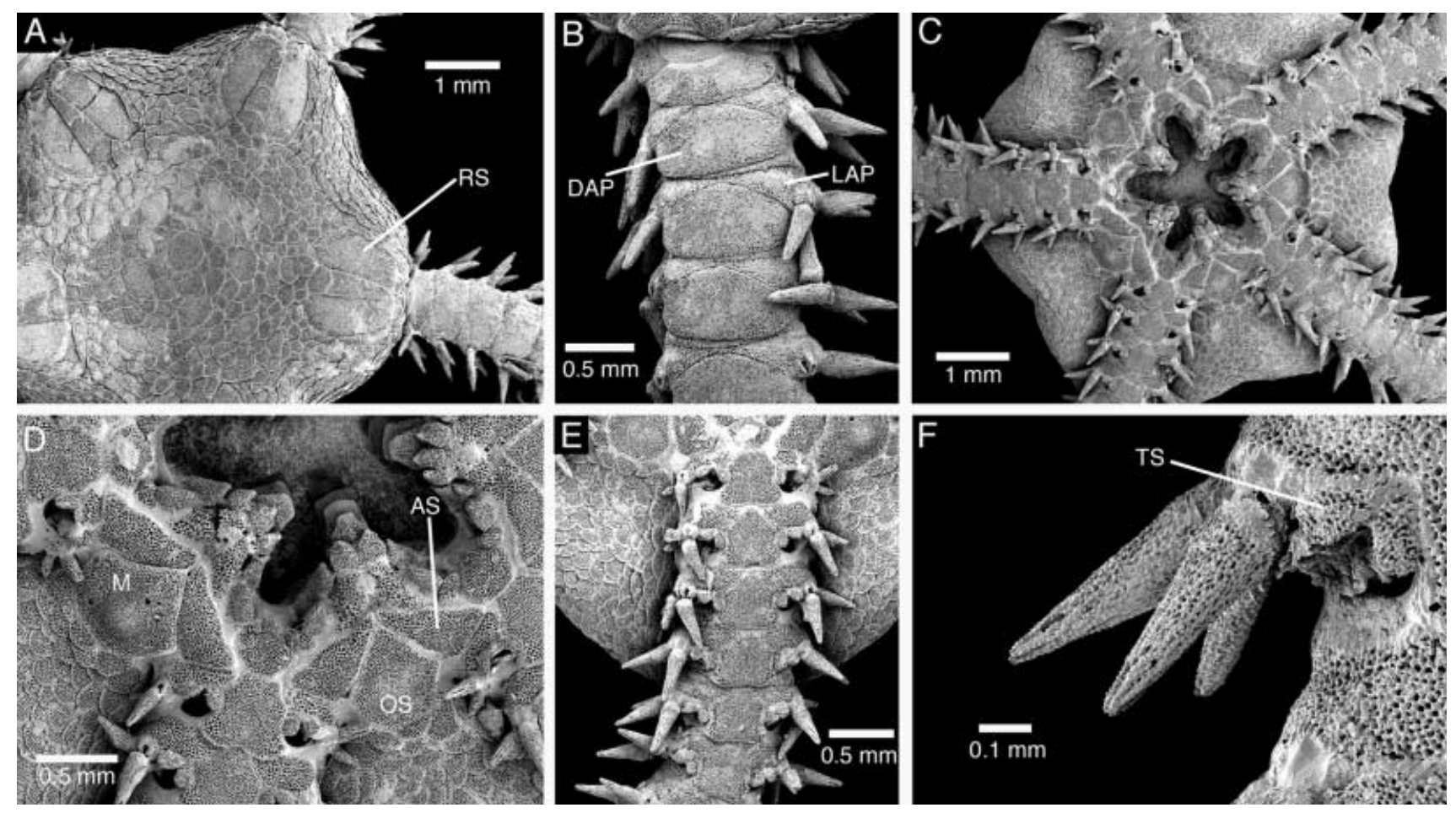

Figure 8. Amphiura sp.: (A) dorsal aspect; (B) arm dorsally, proximal; (G) ventral aspect; (D) oral structures; (E) arm ventrally, proximal; (F) arm spines and tentacle scales. Abbreviations as in Figures 3 and 7.

S. Stöhr, unpublished observations). In O. acies, the distal of the two lateral 'blades' corresponds to the buccal scale, while the proximal 'blade' originates on the lateral edge of the dental plate (Figure 7G) similar to the infradental papillae in Amphiuridae. However, this proximal papilla is present already in the smallest postlarval stage of $O$. acies, while the infradentals of Amphiuridae form at a later stage of development (Hendler, 1978; Sumida et al., 1998; S. Stöhr, unpublished observations). The edge of these wide mouth papillae is strongly serrated in small postlarvae (Figure 7G) and has a rough multilayered structure in larger animals (Figure 7G). The oral shield, particularly the one that forms the madreporite, can be seen already in the smallest stage at the disk edge between the distal ends of the adoral shields (Figure 7A,B), as is common in Ophiuridae (Sumida et al., 1998). The type series has a size gap between $1.0 \mathrm{~mm}$ dd and $2.0 \mathrm{~mm}$ dd. Animals of $1.4 \mathrm{~mm}$ dd from Blake Ridge show a fully developed arm comb (Figure 7D), which is not present at $1.0 \mathrm{~mm}$ dd (Tyler et al., 1995), and the k-plate separating the radial shields proximally like a small wedge has just begun to form at $1.9 \mathrm{~mm}$ dd (Figure $7 \mathrm{E}$ ).

The species can be recognized by its in alcohol light orange, alive more pinkish coloration, disk darker than arms.

\section{Remarks}

Ophioctenella acies is present at all but one (Menez Gwen, $850 \mathrm{~m}$ ) hydrothermal vent sites on the MAR and at all western Atlantic cold seeps studied. However, it reaches its greatest densities at Logatchev and Florida Escarpment, which also have the greatest depth $(>3000 \mathrm{~m})$. On Logatchev, the populations are scattered in several places on the mussel beds, where they are several centimetres thick. Often, a single mussel can be observed surrounded by tens of individuals of $O$. acies, indicating a pronounced preference for mussel proximity. Nevertheless, some ophiuroids can be observed in isolated positions, either on the wall of an active chimney, on sulphide blocks among Zoantharia (Logatchev-Irina 2), or around the active edifices, between sulphide blocks as at Snake Pit-Les Ruches, the only site without mussels. At Lucky Strike, only a few specimens were observed and collected, living on chimneys, among mussels covered by filamentous bacteria, in a diffusing area at $10^{\circ} \mathrm{C}$.

\section{Family AMPHIURIDAE Ljungman, 1867 \\ Genus Amphiura Forbes, 1843 \\ Amphiura sp. \\ (Figure 8)}

\section{Material examined}

One spm, $6 \mathrm{~mm}$ dd, on SEM stub, gold-coated, 3 spms (6.6 mm, $4.4 \mathrm{~mm}, 3.6 \mathrm{~mm} \mathrm{dd}$ ), in alcohol, DIAPISUB (Table 3), collected in mud, with a single Ophioctenella acies, near vestimentiferan Escarpia sp., Bathymodiolus boomerang, gastropods Phymorhynchus aff. alberti, echiura, polychaetes, asteroids.

\section{Diagnosis}

Amphiura over $6 \mathrm{~mm}$ dd, with three tapering arm spines, middle one longest, about an arm segment long. Primary plates distinguishable, particularly the centrodorsal. Dorsal arm plates twice as wide as long, rounded rectangular. Two oval tentacle scales, oral shield teardrop-shaped, two papillae at oral tentacle.

\section{Description}

Disk 3.6-6.6 mm dd, five arms, all broken. Primary plates distinguishable as larger round plates among smaller, round, imbricating scales (Figure 8A). Radial 
shields semicircular, twice as long as wide, 1/4 of dd long, entirely separated by a wedge of several round scales. Dorsal arm plate rectangular, twice as wide as long, adjacent plates separate (Figure 8B). Three tapering arm spines, middle one longest, about an arm segment long (Figure 8B \& F). Ventral disk covered with small round, imbricating scales (Figure 8G). The jaws bear 2-3 pointed infradental papillae, a wide buccal scale deep in the mouth cleft, a wider than long scale-like papilla on the distal oral plate and a smaller oval scale-like papilla on the adoral shield (Figure 8D). Adoral plates elongated triangular, distal edge six times as wide as proximal end, not extending around the angles of the oral shield. Oral shield pentagonal, acute angle with long straight edges, distal lateral edges shorter, straight, distal edge straight or slightly convex, madreporite swollen, with several pores. Ventral arm plate about as long as wide, concave distal edges, acute proximal angle, concave distal edge, adjacent plates just contiguous (Figure 8E). Two oval tentacle scales, one on ventral plate, another on lateral plate (Figure 8F). Colour in alcohol, creamy white.

\section{Remarks}

This species has just three arm spines, a character shared with Amphiura richardi Koehler, 1896 and Amphiura abyssorum Norman, 1876, which both have a partially or completely naked ventral disk and the adoral shields extend around the angles of the oral shield. The dorsal disk of this Amphiura sp. may be confused with Amphiura chiajei Forbes, 1843, from which it differs in the number of spines and the shape of the oral shield. It bears some similarity to the Pacific deep-sea species $A$. diomedeae Lütken \& Mortensen, 1899, which has similar arm spines, disk and arm plates and tentacle scales, but is twice as large, with blueish coloured disk, narrow adoral shields and a conical proximal oral papilla. A literature survey on Amphiura resulted in almost 400 nominal species, many of which have been synonymized over time, but pending a revision it remains one of the largest ophiuroid genera. Descriptions are scattered in the literature of the past 200 years and difficult to access. Although the species presented here is unknown from the North Atlantic, its occurrence in the Pacific Ocean cannot be ruled out and it would be a task beyond the scope of this study to compare it to all described species. We therefore refrain from describing another new species, to avoid further confusion. However, presenting it here is still important, because it was found on a cold seep and may later turn out to be adapted to reducing environments.

\section{Family OPHIACTIDAE Matsumoto, 1915 \\ Genus Ophiactis Lütken, 1856 Ophiactis tyleri sp. nov.}

\section{Holotype}

(Figure 9)

$2.1 \mathrm{~mm}$ dd, dried, mounted on aluminium stub, goldcoated for SEM, MNHN EcOs 22798.

\section{Type locality}

DIVANAUT 1, PL903-11, box 6, 19 May 1994, MAR, 'Segment 38N', 38 ${ }^{\circ} 18.97^{\prime} \mathrm{N} 30^{\circ} 40.54^{\prime} \mathrm{W}, 844 \mathrm{~m}, 19$ May 1994; collected in a bathyal community, in non-vent conditions, on sandstone, with sponges, hydroid Diphasia margareta (Hassall, 1841), dead scleractinian, gorgonaria Anthomastus Verrill, 1878, barnacles and crab Chaceon affinis (Milne-Edwards \& Bouvier, 1894).

\section{Paratype}

$1.4 \mathrm{~mm}$ dd, in ethanol, MNHN EcOh 7002. DIVANAUT 2, PL922-11 (Table 2) in shimmering water zone of $11 \mathrm{C}$, close to a translucent smoker named Mogued Gwen, with mussels fixed on an isolated sulphide rock,
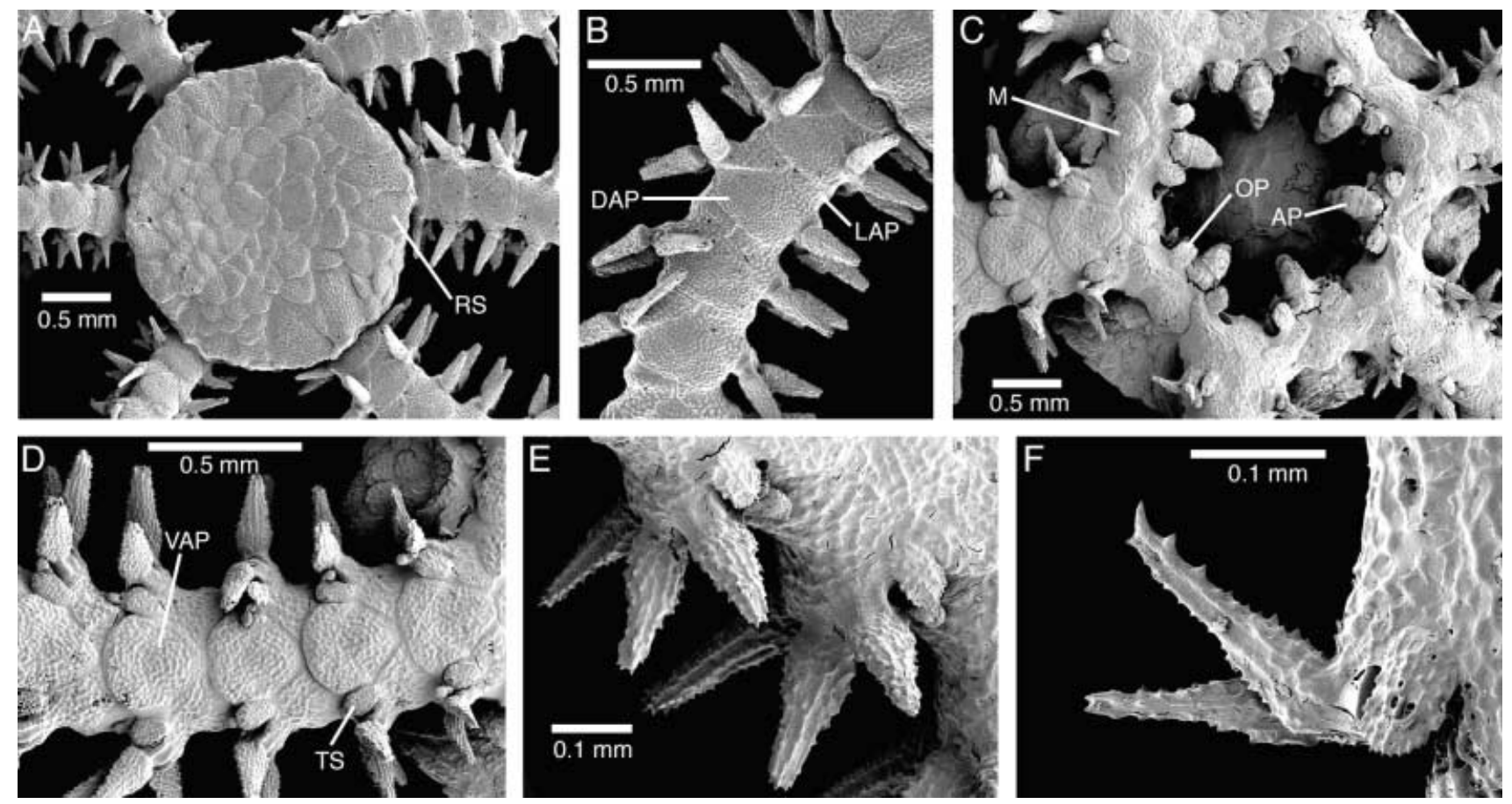

Figure 9. Ophiactis tyleri sp. nov., holotype: (A) dorsal aspect; (B) arm dorsally, proximal; (C) ventral aspect; (D) arm ventrally, proximal; (E) three arm spines proximally and tentacle scale; (F) two arm spines distally, ventral spine hook-like. Abbreviations as in Figures 3 and 7. 
crab C. affinis, polychaetes, gastropods, copepods, many amphipods, shrimps, galatheid crab.

\section{Etymology}

The species is named after Dr Paul Tyler (Southampton Oceanographic Centre, UK), for his contributions to the understanding of the biology of deep-sea ophiuroids.

\section{Diagnosis}

Six-armed fissiparous Ophiactis with smooth dorsal disk, scale borders hard to distinguish, no spines on disk. Three compressed arm spines, middle one broadest, distally only two, ventral one slightly hook-shaped.

\section{Description of holotype}

Disk round, smooth, without spines, $2.1 \mathrm{~mm} \mathrm{dd}$, six arms all broken off $(>2 \times \mathrm{dd})$, two largest, an intermediate and three smaller, indicating previous fission (Figure 9A). Shape and size of skeletal elements differ between parts in different stages of regeneration. Disk scales round, imbricating, perforated all over with large fenestrations. Largest radial shields $0.5 \mathrm{~mm}$ long (about $1 / 4$ of $\mathrm{dd}$ ), separated except at distalmost tip, by a long wedge-like plate and a round proximal scale, smallest radial shields hardly larger than disk scales (Figure 9A). Dorsal arm plate triangular, wider than long, with acute proximal angle, straight, on small arms slightly convex distal edge, separate from following plate (Figure 9B). Three pointed, tapering, dorso-ventrally compressed arm spines with serrated edges, about as long as an arm segment, middle spine broader than the other two, distally two arm spines, ventral spine slightly hookshaped with large terminal tooth and two smaller secondary teeth on ventral edge (Figure 9E,F). Ventral disk covered with round imbricating scales. Apical papilla wider than long, tricuspid (Figure 9G). A single oval oral papilla at adoral shield next to oral tentacle pore, similar in shape and size to tentacle scale. Oral shield about as wide as long, rounded proximal angle with straight to convex edges, strongly convex the distal edge. Madreporite with single large distal pore (Figure 9G). Adoral shields angled, angle twice as wide as proximal end, extending around angles of oral shield. Ventral arm plate pentagonal longer than wide, acute proximal angle, slightly concave lateral sides, convex distal edge (Figure 9D). Single oval tentacle scale covering the pore completely (Figure 9D,E). Bursal slits reach disk edge. Colour in alcohol, white.

\section{Paratype variations}

The paratype with $1.4 \mathrm{~mm}$ dd is smaller than the holotype, but otherwise conforms well with the description.

\section{Remarks}

The genus Ophiactis includes many six-armed fissiparous species, which undergo multiple divisions before reaching maturity. As a result, most specimens are composed of parts in different stages of regeneration and differentiation, causing a great deal of variation in morphology and taxonomic confusion. Most six-armed Ophiactis have thus been described several times and despite later attempts of revision and synonymization the genus is still poorly understood. However, we believe that the description of yet another species is justified because O. tyleri is morphologically different from any known species of Ophiactis. It has its closest affinities with another deep-sea species, the Pacific Ophiactis profundi Lütken \& Mortensen, 1899, which has three (proximally four) round arm spines, none of which is broad and flattened. The single oral papilla of $O$. profundi is pointed. Clark (1918) synonymized O. profundi with $O$. plana, a shallow water species in which he and later authors included several additional nominal species creating a cosmopolitan taxon with great depth range. However, Rowe \& Gates (1995) consider the status of $O$. profundi unresolved and it may represent a distinct deep-water species, so far found only in the Pacific Ocean. The East Atlantic O. nidarosiensis Mortensen, 1920 occurs to a depth of $300 \mathrm{~m}$, has disc spines and the dorsal arm plates are longer than wide. The circumtropical O. savignyi (Müller \& Troschel, 1842) and O. macrolepidota Marktanner-Turneretscher, 1887, the Atlantic/Mediterranean O. virens (M. Sars, 1857), and the Mediterranean O. parva Mortensen, 1926 are all shallow water species (above $100 \mathrm{~m}$ ). Ophiactis savignyi has radial shields $1 / 3$ as long as dd, scattered disk spines and at least 5 arm spines; $O$. parva has disk spines and radial shields $1 / 5$ as long as dd; $O$. virens has a naked ventral disk and lacks bursal slits; O. macrolepidota is similar to O. parva, O. plana Lyman, 1869 and $O$. lymani Ljungman, 1872, and all may be conspecific (Rowe \& Gates, 1995). The Pacific shallow-water (0-10 m) O. simplex (Le Conte, 1851) and O. modesta Brock, 1888 have small radial shields, wide rectangular dorsal arm plates and five arm spines, the latter is also blueish-green in alcohol and has an hour-glass shaped depression in the ventral arm plates (Nielsen, 1932; Liao \& Clark, 1995). The taxonomic status of the tropical West Atlantic O. muelleri Lütken, 1856 is uncertain and it has been synonymized with $O$. savignyi and O. quinqueradia Ljungman, 1872, differing from the new species by disk spines and a larger number of arm spines. Ophiactis hirta Lyman, 1879 from New Zealand/Australian waters has disc spines, 2-3 oral papillae at each jaw edge and four arm spines. Ophiactis brachyura Döderlein, 1898 has extremely short arms $(2 \times \mathrm{dd})$ and at least four arm spines. Other species include O. algicola H.L. Clark, 1933, O. rubropoda Singletary, 1973 and O. notabilis H.L. Clark, 1939, all extremely shallow-living (0-24 m; Hendler et al., 1995) with at least four arm spines and thus unlikely to be conspecific with O. tyleri. Ophiactis loricata Lyman, 1869 from Florida $(200 \mathrm{~m})$ bears disk spines and two oral papillae. Ophiactis dyscrita H.L. Clark, 1911 differs from O. tyleri by its long and narrow radial shields, oval oral shield, small oral papilla and absence of hook-shaped spines.

Among six-armed Ophiactis known from the Atlantic, O. tyleri occurs at the greatest depth and it is the only Ophiactis found at a hydrothermal vent. Together with Ophiotreta valenciennesi rufescens, this is the second ophiuroid species found in vent conditions at a site where Ophioctenella acies is absent.

\section{DISCUSSION}

\section{Distribution of Ophioctenella acies}

Since its discovery at Snake Pit and TAG on the MAR, Ophioctenella acies has been reported from several additional sites: Logatchev (Gebruk et al., 2000), Lucky 
Strike and Rainbow (Desbruyères et al., 2001), and from the cold seeps at Florida Escarpment (Turnipseed et al., 2004) and Blake Ridge (Van Dover et al., 2003). 'Slender pink ophiuroids', most likely $O$. acies, were reported in the first description of a cold seep community at Florida Escarpment (Hecker, 1985). The present study confirms these records and reports $O$. acies for the first time from the Barbados accretionary prism cold seep area (south of Barbados). The species reaches its highest densities at depths greater than $3000 \mathrm{~m}$ : 20 ind $\mathrm{dm}^{-2}$ at Snake PitElan, $3500 \mathrm{~m}$ (Tyler et al., 1995), 80 ind $\mathrm{dm}^{-2}$ at Logatchev, $3020 \mathrm{~m}$ (Gebruk et al., 2000), and probably even higher densities at some places on this site, according to the documentation video. At the shallowest vent site Menez Gwen, O. acies has not been observed. The species is abundant on the cold-seeps of Blake Ridge (Van Dover et al., 2003) and Florida Escarpment (Turnipseed et al., 2004), but rare at south Barbados (only one specimen collected, maybe because of inadequate sampling mode).

Ophioctenella acies is associated with mussel beds at all sites, except Snake Pit-Les Ruches, where mussels are absent. It occurs also among the vesicomyid clams Calyptogena (Ectenagena) aff. kaikoi at Logatchev-Anya's Garden (Gebruck et al., 2000) and at Blake Ridge (Van Dover et al., 2003). On the MAR vent sites, the ophiuroids aggregate among the mussels, on or very close to the shimmering water zone (fluid/seawater mixing zone). The emitted fluids with temperatures between 4 and $16^{\circ} \mathrm{C}$, contain high levels of 'toxic' heavy metals, e.g. $\mathrm{Cu}, \mathrm{Pb}$, Cd (Sarradin et al., 1999; Desbruyères et al., 2000). These concentrations are not a constraining factor in explaining the current distribution of $O$. acies since they are abundant also on the cold-seep sites where the fluids are depleted in metal compounds. Tyler et al. (1995) suggested that $O$. acies may be detritivorous, ingesting organic matter produced by the shrimp and mussel populations, or bacterial films on sulphide particles. Our video observation shows that specimens sometimes stay on open siphons of mussels where they may collect pseudo-faeces rejected by the mussels. Although the majority of ophiuroids observed do not present this behaviour, it is probable that the pseudo-faeces of mussels constitute a significant source of organic matter available. Sarradin et al. (1999) found that the mussel activity depletes the medium of sulphide and nitrate, and enriches it in dissolved organic matter and ammonia. Presuming the same phenomenon takes place on the mussel populations on the other sites (vents and cold-seeps), we hypothesize that the ophiuroids may benefit from this enrichment of the medium in dissolved organic carbon. Stable isotope studies are needed to understand the position of $O$. acies in the trophic chain of the reduced environment communities.

Considering that cold seep and vent communities have been found to have a high degree of endemicity among both symbiont-bearing and non-symbiont-bearing species (Sibuet \& Olu, 1998), the habitat distribution of O. acies is remarkably wide. It is one of the few species shared by hydrothermal vent and cold seep sites. It is, however, surprising that the monospecific genus Ophioctenella apparently has not diversified, contrary to the genus Bathymodiolus, with which it is associated. The wide distribution of $O$. acies is not consistent with the suggestion that the similarity of the endemic fauna between four MAR hydrothermal vent sites are a function of the distance (Desbruyères et al., 2000).

The current distribution of $O$. acies raises another question. How can the gene flow between western Atlantic cold seep populations and those of the MAR vent sites be maintained? Deep-ocean currents in the western Atlantic transporting cold northern waters southward along transform faults, with several eastwards diverging flows south of the equator may serve as larvae carriers to establish a link between the fauna of western Atlantic seeps and the vent field Logatchev on the MAR and ultimately to cold seeps off the African coast (Van Dover et al., 2002). These unidirectional flows suggest that organisms found on both seeps and vents may have evolved on western cold seeps from which they were transported eastward, colonizing suitable sites along the way (Craddock et al., 1995). However, samplings recently carried out on the West African margin found only few ophiuroids, among which $O$. acies does not occur (M. Sibuet, unpublished data). On the other hand, movements as well as temperature and salinity characteristics of Atlantic water masses were different during the Quaternary glacial-interglacial cycles (Duplessy et al., 2002), and most probably during earlier geological eras. Based on this observation, the current large-scale distribution of $O$. acies could perhaps be explained as the result of an ancient spreading phase, leaving current populations isolated without genetic exchanges and apparently also without morphological diversification. In fact, several genera restricted to reducing environments, i.e. Bathymodiolus spp. and Escarpia spp., are shared by communities of western Atlantic cold seeps (Florida Escarpment, Blake Ridge and south Barbados) and those of the west equatorial African margin. The shrimp species Alvinocaris muricola is even present in both assemblages (west African margin and Florida Escarpment; Komai \& Segonzac, in press). Molecular studies are needed to rule out the possibility of cryptic species and/or barriers to gene flow between populations of a single species among the morphologically similar populations of $O$. acies. On a regional scale, along the MAR axis and between cold seep sites, flows are more difficult to assess and further study is needed. Mullineaux et al. (2002) showed that larvae of vent organisms may disperse with hydrothermal plumes, which rise several hundred metres above the sea-floor and spread laterally, in addition to near-bottom currents. A strong relationship between larval life-span and the flow regime at vent sites determines dispersal distances in the Pacific tubeworm Riftia pachyptila Jones, 1981 (Marsh et al., 2001). The small size of the earliest post-larva of $O$. acies suggests planktotrophic development. Consequently, gene flow between northern MAR vent sites may be possible via planktonic larvae. But several details constrain this hypothesis: lack of knowledge of the axial current characteristics, the presence of significant transform faults, probably involving strong larval losses off-axis, and finally, the life-span of the larva of $O$. acies is unknown. Most samples of $O$. acies from all sites contain individuals of different ages, from early post-larvae to adults, indicating regular successful recruitment, but whether the eggs and larvae disperse in the plankton or stay close to their source population is not known. Reproduction studies on O. acies are currently under way (P. Tyler, personal communication) and may shed some light on these questions. 
So far, O. acies seems restricted to the Atlantic Ocean, which is not surprising since $85 \%$ of bathyal echinoderms and other deep-sea fauna occur in only one ocean (Ekman, 1953; Vinogradova, 1979). Indeed, at hydrothermal vents on the East Pacific Rise, a still undescribed species of Ophiura is abundant (own unpublished observation) and probably restricted to reducing environments.

\section{Other ophiuroid species at hydrothermal vents}

This study for the first time reports five different species of ophiuroids from the shallowest site on the MAR, Menez Gwen, two of them previously unknown. However, only two species, Ophiactis tyleri and Ophiotreta valenciennesi rufescens, were found in hydrothermal conditions and Ophioctenella acies is absent. Hydrothermal fluids at this site are depleted of metals because of the lower hydrostatic pressure (Sarradin et al., 1999; Desbruyères et al., 2000), possibly explaining the presence of non-hydrothermal species. Indeed, a larger number of non-hydrothermal species from other taxa have been observed at Menez Gwen (Desbruyères et al., 2000), but no ophiuroids had been found before. However, the lower toxicity of certain hydrothermal fluids appears not to be the only explanation for the occurrence of non-hydrothermal species at vent sites, since we found three other species, Ophiocten centobi, Ophiomitra spinea and Ophiura clemens, at several deeper hydrothermal sites. In fact, we think that the high number of non-vent species at Menez Gwen results from the higher species numbers in the surrounding bathyal fauna compared with the species-poorer fauna surrounding the deeper sites. Among the non-hydrothermal species only Ophiura clemens was found in the same spot as Ophioctenella acies, which is the strongest support that it actually lived under hydrothermal conditions. The other species were found close to sampling sites where $O$. acies has been collected, but not in exactly the same sample. Whether this reflects differences in local biochemical conditions is not yet known. Additional sampling is needed to ascertain whether these species actually live under the same hydrothermal conditions as $O$. acies or in a more diluted, less extreme border zone. Perhaps these records only reflect rare accidental settling events of ecologically flexible species.

Six species (Ophiactis abyssicola, Ophiura ljungmani, Ophiacantha crassidens, Ophiacantha smitti, Ophiomitra spinea, Ophiotreta valenciennesi rufescens) are known from both sides of the Atlantic, while seven others (Ophioplinthaca carduus, Ophiacantha enopla veterna, Asteroschema inornatum, Ophiacantha notata, Ophiactis abyssicola, Ophiura clemens, Ophiocten centobi) are only known from the East Atlantic (Paterson, 1985; this paper), but their presence on the MAR suggests that they may occur also further eastwards, which would contradict the suggestion that the MAR is a natural boundary of dispersal for bottom fauna (Vinogradova, 1979).

\section{Ophiuroids in cold seep habitats}

With Ophienigma spinilimbatum, the second ophiuroid species restricted to chemosynthetic environments is described. Despite an extensive collection effort at the MAR vent sites, no specimens of this species were found and it is not likely to occur there. Instead, the geographic distribution of Ophienigma spinilimbatum is probably restricted to cold seeps. Like Ophioctenella acies it represents a previously unknown genus, but it appears not to possess any novel morphological adaptations to the reducing environment. No small juveniles were found in the samples, which raises questions about the reproductive mode and recruitment success of the species. Ophienigma spinilimbatum appears to be associated with both mussels and tubeworms.

The presence of Ophiotreta valenciennesi rufescens in the Gulf of Mexico cold seeps was surprising, since the species was previously known only from the East Atlantic. It appears to be associated with Lophelia corals at this site. It is also one of few species occurring in three types of environments, seeps, vents and non-reducing bathyal.

In contrast to Ophienigma spinilimbatum, Ophioctenella acies with its specialized mouth parts seems derived, and its wide geographic distribution suggests a greater age of the species, but more information is needed on the evolution of ophiuroid skeletal structures or spreading mechanisms of species to support this hypothesis. Their coexistence at Blake Ridge suggests different ecological adaptations, which remain to be studied. Both species belong to monotypic genera unknown from other places and their phylogenetic relationships with other species are not understood yet. They belong to the two families of ophiuroids, which are most species-rich in the deepsea.

Two previously unknown species, Ophiacantha longispina and Amphiura sp., were collected at the south Barbados seep site. The small number of individuals may suggest that they are not restricted to the seep environment. However, densities seem generally low, with only a single Ophioctenella acies collected, or perhaps the collecting mode was inadequate for this site. Ophioplinthaca chelys, which was also found at the site, has been reported from both sides of the Atlantic and also from the Pacific Ocean (Paterson, 1985).

\section{Conclusions}

Although ophiuroids are still an underrepresented group at hydrothermal vents and cold seeps, this analysis shows that they probably regularly colonize these environments and that they have been undercollected. Reproductive strategies, dispersal modes, ecological adaptations and phylogenetic relationships of both endemic and colonizing species are not yet understood and require additional collecting efforts. Most of the newly discovered species occur in non-reducing habitats, demonstrating how incompletely known the deep-sea fauna still is even in a well studied area such as the North Atlantic Ocean.

We are very grateful to Cindy L. Van Dover for generously releasing some of her samples to this study and for supplying Figure 2A, to Eric Cordes (Penn State University) for submitting his samples from the Gulf of Mexico, and to the chief scientists: H. Bougault, Y. Fouquet, D. Desbruyères, A.-M. Alayse, P.-M. Sarradin \& V. Trenkel (Ifremer), F. Barriga (University of Lisbon), J.-C. Faugères (University of Bordeaux), D. Prieur (UBO, Brest), C. Van Dover \& I. Macdonald (USA), G. Fisher (USA), and G. Gudmundsson (BIOice, Reykjavik). Many thanks to Violaine Martin (Ifremer) for Figure 1, and to Maria Byrne (Sydney), Thierry Comtet and Didier Jollivet (Roscoff), Pierre 
Chevaldonné (Marseille), Bruno David (Dijon), Daniel Desbruyères and Karine Olu (Ifremer), and Anders Warén (Stockholm) for critical comments on an early version of the manuscript. Many thanks also to four anonymous referees who kindly helped to improve the manuscript.

\section{REFERENCES}

Clark, H.L., 1918. Brittle stars, new and old. Bulletin of the Museum of Comparative Zoology, 62, 263-338.

Cosel, R. von \& Marshall, B.A., 2003. Two new species of large mussels (Bivalvia: Mytilidae) from active submarine volcanoes and a cold seep off the eastern North Island of New Zealand, with description of a new genus. The Nautilus, 117, 31-46.

Craddock, C., Hoek, W.R., Gustafson, R.G., Lutz, R.A., Hashimoto, J. \& Vrijenhoek, R.J., 1995. Evolutionary relationships among deep-sea mytilids (Bivalvia: Mytilidae) from hydrothermal vents and cold-water methane/sulfide seeps. Marine Biology, 121, 477-485.

Desbruyères, D., Alayse-Danet, A.-M., Ohta, S. \& the Scientific Parties of Biolau \& Starmer cruises, 1994. Deep-sea hydrothermal communities in southern Pacific back-arc basins (the North Fiji and Lau Basins): composition, microdistribution and food-web. Marine Geology, 116, 227-242.

Desbruyères, D., Almeida, A., Biscoito, M., Comtet, T., Khripounoff, A., Le Bris, N., Sarradin, P.M. \& Segonzac, M., 2000. A review of the distribution of hydrothermal vent communities along the northern Mid-Atlantic Ridge: dispersal vs. environmental controls. Hydrobiologia, 440, 201-216.

Desbruyères, D. et al., 2001. Variations in deep-sea hydrothermal vent communities on the Mid-Atlantic Ridge near the Azores plateau. Deep-Sea Research I, 48, 1325-1346.

Desbruyères, D. \& Segonzac, M., 1997. Handbook of deep-sea hydrothermal vent fauna. Brest: Editions Ifremer.

Duplessy, J.C., Labeyrie, L. \& Waelbrock, C., 2002. Constraints on the oxygen isotopic enrichment between the last glacial maximum and the holocene: palaeoceanographic implications. Quarternary Science Reviews, 21, 315-330.

Ekman, S., 1953. Betrachtungen über die Fauna der abyssalen Ozeanböden. XIV. International Zoological Congress, Copenhagen 1953. IUBS Deep Sea Colloquium, 4 pp.

Gage, J.D. \& Tyler, P.A., 1991. Deep-sea biology: a natural history of organisms at the deep-sea floor. New York: Cambridge University Press.

Gebruk, A.V., Chevaldonné, P., Shank, T., Lutz, R.A. \& Vrijenhoek, R.C., 2000. Deep-sea hydrothermal vent communities of the Logatchev area $\left(14^{\circ} 45^{\prime} \mathrm{N}\right.$, Mid-Atlantic Ridge): diverse biotopes and high biomass. Fournal of the Marine Biological Association of the United Kingdom, 80, 383-393.

Halanych, K.M., Tieger, M., O’Mullan, G.D., Lutz, R.A. \& Vrijenhoek. R.C., 1999. Brief description of biological communities at $7^{\circ} \mathrm{S}$ on the Eastern Pacific Rise. InterRidge, 8, 23-27.

Hecker, B., 1985. Fauna from a cold sulfur-seep in the Gulf of Mexico: comparison with hydrothermal vent communities and evolutionary implications. Bulletin of the Biological Society of Washington, 6, 465-473.

Hendler, G., 1978. Development of Amphioplus abditus (Verrill) (Echinodermata: Ophiuroidea). II. Description and discussion of ophiuroid skeletal ontogeny and homologies. Biological Bulletin. Marine Biological Laboratory, Woods Hole, 154, 79-95.

Hendler, G., Miller, J.E., Pawson, D.L. \& Kier, P.M., 1995. Sea stars, sea urchins and allies. Washington \& London: Smithsonian Institution Press.

Komai, T. \& Segonzac, M., in press. A revision of the genus Alvinocaris Williams and Chace (Crustacea: Decapoda: Caridea: Alvinocarididae), with descriptions of a new genus and a new species of Alvinocaris. Fournal of Natural History.

Liao, Y. \& Clark, A.M., 1995. The echinoderms of Southern China. Beijing, New York: Science Press.
Marsh, A.G., Mullineaux, L.S., Young, G.M. \& Manahan, D.T., 2001. Larval dispersal potential of the tubeworm Riftia pachyptila at deep-sea hydrothermal vents. Nature, London, 411, 77-80.

Mortensen, T., 1927. Handbook of the echinoderms of the British Isles, reprint 1977. Rotterdam: Backhuys.

Mortensen, T., 1933. Echinoderms of South Africa. Videnskabelige Meddelelser fra Dansk Naturhistorisk Forening, 93, 215-400.

Mullineaux, L.S., Speer, K.G., Thurnherr, A.M., Maltruid, M.E. \& Vangriesheim, A., 2002. Implications of cross-axis flow larval dispersal along mid-ocean ridges. Cahiers de Biologie Marine, 43, 281-284.

Nielsen, E., 1932. Ophiurans from the Gulf of Panama, California, and the Strait of Georgia. Videnskabelige Meddelelser fra Dansk Naturhistorisk Forening, 91, 241-346.

O'Hara, T.D. \& Stöhr, S., in press. Deep water ophiuroids of New Caledonia: Ophiacanthidae and Hemieuryalidae. Tropical Deep Sea Benthos.

Paterson, G.L.J., 1985. The deep-sea Ophiuroidea of the North Atlantic Ocean. Bulletin of the British Museum (Natural History), (Zoology), 49, 1-162.

Paterson, G.L.J., Tyler, P.A. \& Gage, J.D., 1982. The taxonomy and zoogeography of the genus Ophiocten (Echinodermata: Ophiuroidea) in the North Atlantic Ocean. Bulletin of the British Museum (Natural History) (Zoology), 43, 109-128.

Rowe, F.W.E. \& Gates, J., 1995. Echinodermata. In Zoological catalogue of Australia, vol. 33 (ed. A. Wells). Melbourne: CSIRO Australia.

Sarradin, P.-M., Caprais, J.-C., Riso, R., Kerouel \& Aminot, R.A., 1999. Chemical environment of the hydrothermal mussel communities in the Lucky Strike and Menez Gwen vent fields, Mid Atlantic Ridge. Cahiers de Biologie Marine, 40, 93-104.

Segonzac, M., 1992. Les peuplements associés à l'hydrothermalisme océanique du Snake Pit (dorsale médio-atlantique; $23^{\circ} \mathrm{N}$, $3480 \mathrm{~m}$ ): composition et microdistribution de la mégafaune. Comptes Rendus de l'Académie des Sciences. Paris, 314(III), 593-600.

Sibuet, M. \& Olu, K., 1998. Biogeography, biodiversity and fluid dependence of deep-sea cold-seep communities at active and passive margins. Deep-Sea Research II, 45, 517-567.

Smith, A.B., Paterson, G.L.J. \& Lafay, B., 1995. Ophiuroid phylogeny and higher taxonomy: morphological, molecular and palaeontological perspectives. Zoological Fournal of the Linnean Society, 114, 213-243.

Sumida, P.Y.G., Tyler, P.A., Gage, J.D. \& Nørrevang, A., 1998. Postlarval development in shallow and deep-sea ophiuroids (Echinodermata: Ophiuroidea) of the NE Atlantic Ocean. Zoological Fournal of the Linnean Society, 124, 267-300.

Turnipseed, M., Jenkins, C.D. \& Van Dover, C.L., 2004. Community structure in Florida Escarpment seep and Snake Pit (Mid-Atlantic Ridge) vent mussel beds. Marine Biology, 145, 121-132.

Tyler, P.A., German, C.R., Ramirez-Llodra, E. \& Van Dover, C., 2003. Understanding the biogeography of chemosynthetic ecosystems. Oceanologica Acta, 25, 227-241.

Tyler, P.A., Paterson, G.J.L., Sibuet, M., Guille, A., Murtons, B.J. \& Segonzac, M., 1995. A new genus of ophiuroid (Echinodermata: Ophiuroidea) from hydrothermal mounds along the Mid-Atlantic Ridge. Fournal of the Marine Biological Association of the United Kingdom, 75, 977-986.

Vadon, C., 1991. Ophiuridae profonds de Nouvelle-Calédonie. Formes paedomorphes. In Résultats des Campagnes MUSORSTOM (ed. A. Crosnier), vol. 8. Mémoires Museum national d'Histoire Naturelle, (A), 151, 335-356.

Van Dover, C.L., 2002. Evolution and biogeography of deep-sea vent and seep invertebrates. Science, New York, 295, 1253-1257.

Van Dover, C.L. et al., 2003. Blake Ridge methane seeps: characterization of a soft-sediment, chemosynthetically based ecosystem. Deep-Sea Research I, 50, 281-300. 
Van Dover, C.L., Desbruyères, D., Segonzac, M., Comtet, T., Saldanha, L., Fiala-Médioni, A. \& Langmuir, C., 1996. Biology of the Lucky Strike hydrothermal field. Deep-Sea Research, 43, 1509-1529.

Vinogradova, N.G., 1979. The geographical distributions of the abyssal and hadal (ultra-abyssal) fauna in relation to the vertical zonation of the ocean. Sarsia, 64, 41-50.
Won, Y.-J., Maas, P.A.Y., Van Dover, G.L. \& Vrijenhoek, R.C., 2002. Habitat reversal in vent and seep mussels: seep species, Bathymodiolus heckerae, derived from vent ancestors. Cahiers de Biologie Marine, 43, 387-390.

Submitted 15 April 2004. Accepted 1 December 2004. 